Article

\title{
Rural Public Acceptance of Wind and Solar Energy: A Case Study from Mersing, Malaysia
}

\author{
Muhammad Aslam Mohd Safari ${ }^{1}$, Nurulkamal Masseran ${ }^{2, *}$, Alias Jedi ${ }^{3}{ }^{\circledR}$, Sohif Mat ${ }^{3,4}$, \\ Kamaruzzaman Sopian ${ }^{3,4}$, Azman Bin Abdul Rahim ${ }^{5}$ and Azami Zaharim ${ }^{3,4}$ \\ 1 Institute of Mathematical Sciences, Faculty of Science, Universiti Malaya, Kuala Lumpur 50603, Malaysia; \\ aslammohdsafari@gmail.com \\ 2 Department of Mathematical Sciences, Faculty of Science and Technology, Universiti Kebangsaan Malaysia, \\ Bangi 43600, Selangor, Malaysia \\ 3 Faculty of Engineering \& Built Environment, Universiti Kebangsaan Malaysia, \\ Bangi 43600, Selangor, Malaysia; aliasjedi@ukm.edu.my (A.J.); sohif@ukm.edu.my (S.M.); \\ ksopian@ukm.edu.my (K.S.); azami@ukm.edu.my (A.Z.) \\ 4 Solar Energy Research Institute, Universiti Kebangsaan Malaysia, Bangi 43600, Selangor, Malaysia \\ 5 Marine Ecosystem Research Centre (EKOMAR), Universiti Kebangsaan Malaysia, \\ Bangi 43600, Selangor, Malaysia; abarahim@ukm.edu.my \\ * Correspondence: kamalmsn@ukm.edu.my; Tel.: +60-3-8921-3424
}

Received: 30 May 2020; Accepted: 23 July 2020; Published: 28 July 2020

\begin{abstract}
The sustainable development of the energy sector through the implementation of renewable energy (RE) technology has been a primary concern for the government of Malaysia since the 1990s. Developing RE technology in rural areas is also one of the most important energy strategies. One of the most important requirements for the successful adoption of renewable energy technology is the public acceptance of this technology. This article examines the public acceptance of RE (wind and solar) technologies among rural residents in Mersing, Malaysia. This study is conducted in conjunction with the development of the hybrid wind-solar RE generation system for the Marine Ecosystem Research Centre (EKOMAR), which located in Mersing. To investigate the public acceptance of RE technologies, two surveys were conducted, before and after the installation of the hybrid wind-solar $\mathrm{RE}$ generation system. The findings revealed that RE innovations, such as wind and solar energy, were well known among $54.7 \%$ and $96.2 \%$ of the respondents, respectively, before and after the introduction of EKOMAR. The survey results showed that rural residents generally support RE technologies and EKOMAR RE projects. They were also in line that the use of RE should also be extended to other parts of Mersing, including wind and solar. These findings illustrate that EKOMAR has played a crucial role in educating local residents about RE, wind and solar energy in particular. Residents believe the government plays an important role, particularly in rural areas, in encouraging and enhancing RE technologies.
\end{abstract}

Keywords: rural public acceptance; renewable energy; standalone; hybrid wind-solar

\section{Introduction}

\subsection{The Features of Energy Production Structure in Malaysia}

In Malaysia, crude oil, coal, natural gas and hydropower are the primary energy sources available. Malaysia has seen an increasing pattern over the past 37 years between 1978 and 2014 in the overall energy supply from these main sources, as shown in Figure 1. The largest source of electricity in Malaysia since 1978 has been natural gas and crude oil, led by coal. Hydropower, the primary source of renewable energy (RE) that contributes significantly towards the supply of electricity in Malaysia 
in 2014 [1] provides just 4.741 MW of electricity, given the fact that Malaysia estimates hydropower capacity at 29,000 MW [2].

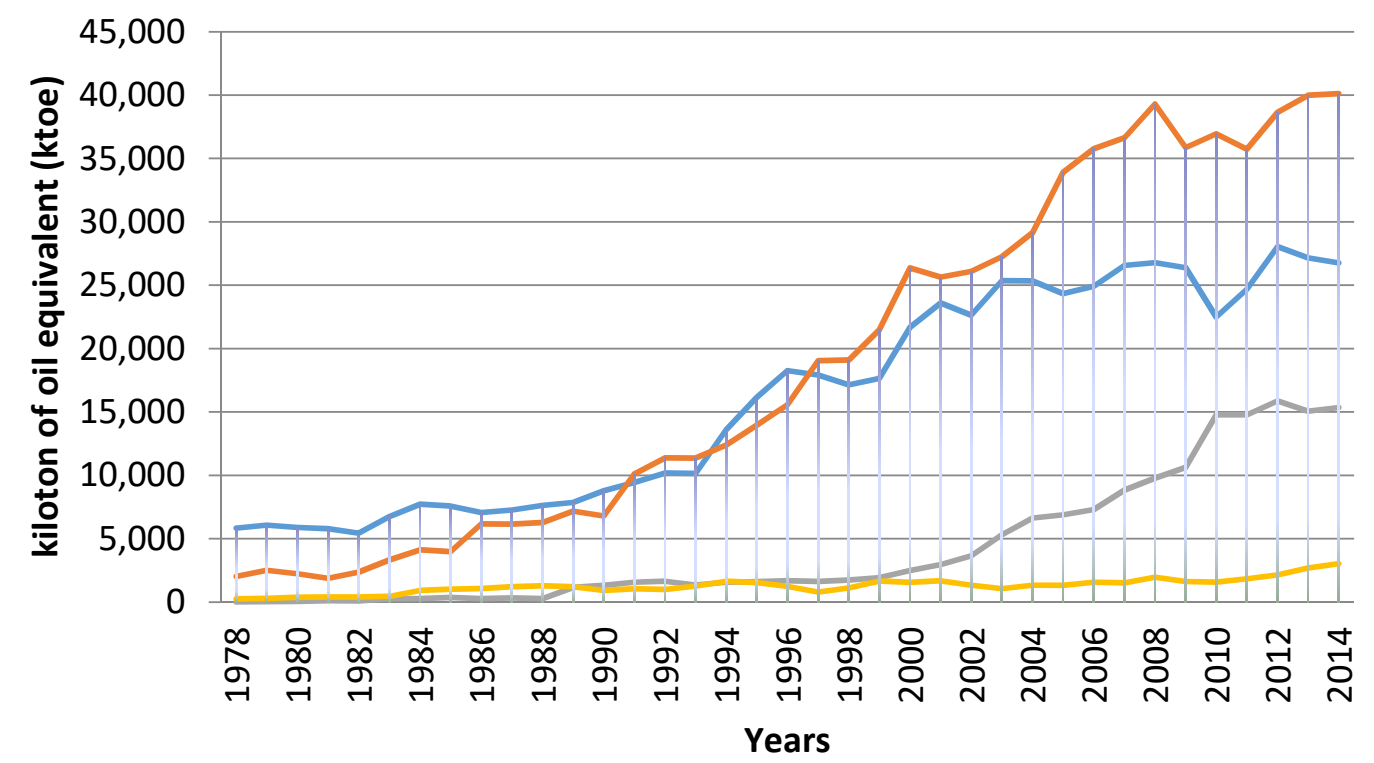

Crude Oil $\longrightarrow$ Natural Gas Coal and Coke $\quad$ Hydropower

Figure 1. Sources of primary energy supply in Malaysia (source: Malaysia Energy Information Hub [3]).

It has been reported that Malaysia's total energy supply from primary sources was 85.273 Mtoe in 2014 with industrial and transport sectors accounting for the majority of the energy consumption, as shown in Figure 2. Figure 2 reveals that Malaysia's energy demands can be split into five major sectors: manufacturing, transport, residential/commercial, non-energy and agriculture. Nevertheless, it is clear that, amid a substantial reduction in the output of the manufacturing sector, the greatest total rise in energy consumption is induced by the rising demand of the transport industry.

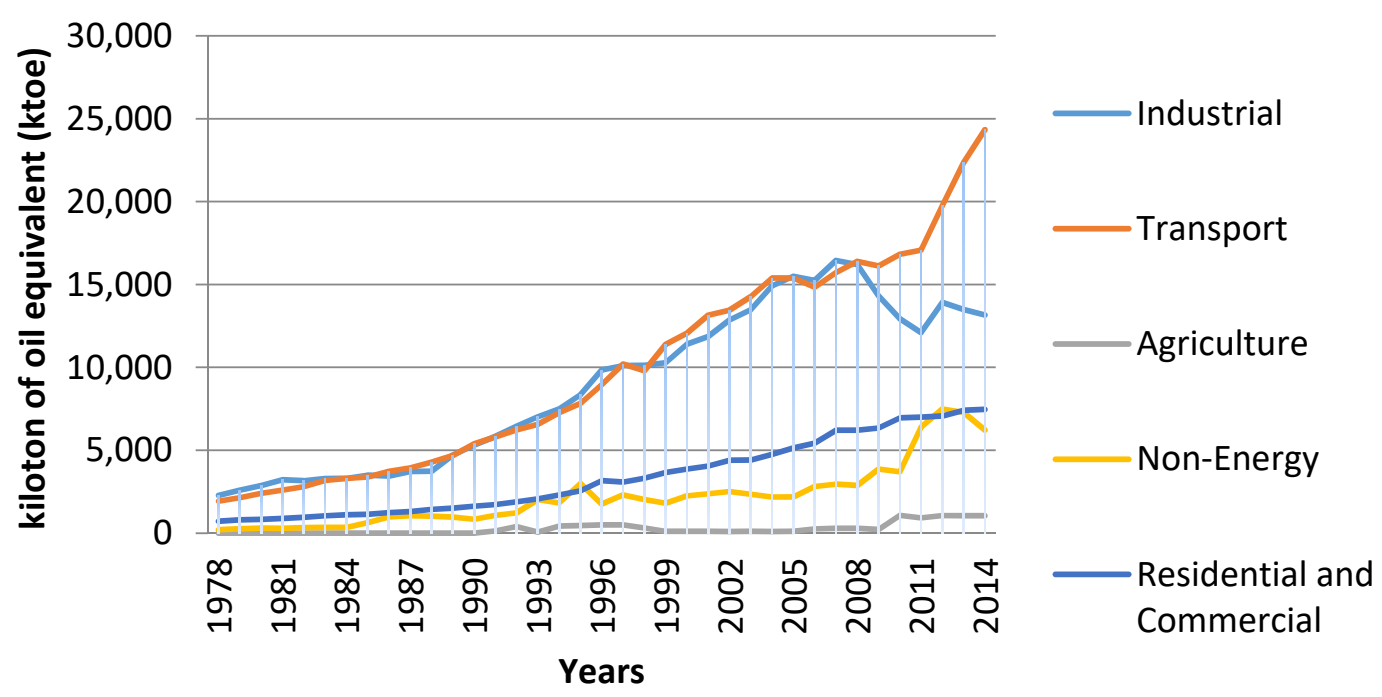

Figure 2. Energy demand in Malaysia by sector (source: Malaysia Energy Information Hub [3]).

Malaysia has been categorized as a developing country, owing to its increasing energy consumption [2,4]. This increase has also caused Malaysia to be highly dependent on fossil fuels, such as gas, coal and oil [5-7]. However, these sources will soon be completely depleted. Maggio and Cacciola [8] found that the peak 
production for oil occurred between 2009 and 2021, whereas that for gas will occur between 2024 and 2046, while that for coal will occur between 2042 and 2062. They also estimated that coal reserves will be the only fossil fuel source remaining after 2250. Moreover, energy production from the combustion of fossil fuels has created several environmental issues, including the emission of GHG with carbon dioxide $\left(\mathrm{CO}_{2}\right)$ as the primary contributor, thereby hastening global warming [9-12]. $\mathrm{CO}_{2}$ emissions have been found to be increasing since 1960 in Malaysia as well as across the globe (Figure 3). Global $\mathrm{CO}_{2}$ emissions grew from 9106.56 million tons in 1960 to 34,782.58 million tons in 2015, while $\mathrm{CO}_{2}$ levels rose from 4.02 million tons in 1960 in Malaysia to 248.74 million tons in 2015. Unless restrictions are carried out, $\mathrm{CO}_{2}$ emissions in Malaysia are expected to hit 285.73 million tons by 2020 [13]. Therefore, the potential estimated $\mathrm{CO}_{2}$ emissions from the burning of fossil fuels from current infrastructures measured will be at 496 gigatons between 2010 and 2060 (ranging from 282 to 701 gigatons) [14]. In fact, $\mathrm{CO}_{2}$ pollution from fossil-fuel burning has been warned of major impacts on long-term oxygen loss and the expansion of ocean oxygen-minimum zones [15]. Based on all these issues, it can be concluded that it is very important to enhance the awareness of RE technologies to consume more efficient and environmentally friendly energy.

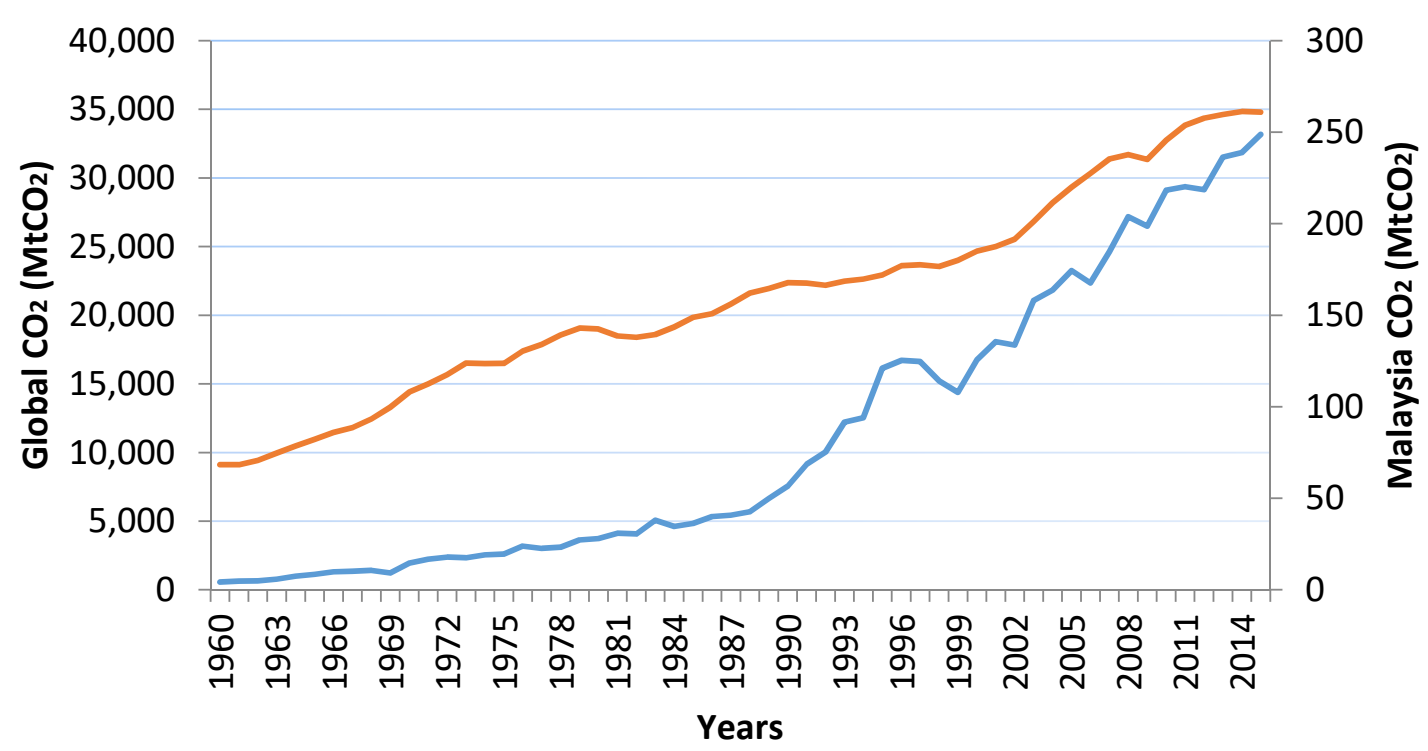

Global CO2 Malaysia CO2

Figure 3. Global and Malaysian carbon dioxide emission from 1960 to 2015 (source: CDIAC, UNFCCC and BP [16]).

\subsection{The Possibilities, Challenges and Actions in the Scope of Promotion and Proliferation of RES}

Among the efficient development programs that reduce reliance upon fossil fuel, the efficient use of renewable energy (RE) technologies, such as biomass, biofuel, biodiesel, solar and wind, which led to the reduction in climate change effects, are included [11]. In addition, RE provides tremendous sustainability potential and is growing as an option that is technologically feasible, commercially competitive and socially acceptable [17]. The Malaysian government has been dealing mainly with the problems of renewable energy (RE) since 1990. As a first action, the government adopted RE as the fifth fuel method in the energy mix as a part of the 1999 National Energy Policy focusing on sustainability and efficiency $[6,9,10,18]$. Since then, Malaysia's government has focused on energy conservation in the manufacturing, commercial, residential and domestic sectors. This was achieved by the use of RE and the introduction of emerging RE sources including biofuels, landfill gas, limited hydro and solar electricity, while still increasing energy supplies sustainably [9]. Although RE is still in its early stage in Malaysia, significant attempts have been made to improve and foster the use of RE resources through government policies and programs. 
Different initiatives were pursued by the Malaysian government with the aim of maintaining sustainable resources in the future, such as the Five-Fuel Policy (2000), the National Biofuel Policy (2006), the National Green Power Policy (2009) and the National Renewable Energy Policy (2010) [5,7,19]. The main objective of the implementation of such policies is to encourage communities and individuals to consider RE as an alternate energy source [5]. Moreover, many RE projects have been initiated by the government to support these RE policies, such as the Small Renewable Energy Power (SREP) program, the Biomass Power Generation and Demonstration (BioGen) project, the Malaysia Building Integrated Photovoltaic Technology Application (MBIPV), as well as the Centre for Education and Training in Renewable Energy and Energy Efficiency (CETREE) [5,19]. The government has also developed incentives, funds and funding schemes to promote growth in the use of RE in Malaysia [5,19].

Sustainable energy production in Malaysia remains a major problem in the energy sector. Although existing policies, initiatives and incentives have been designed to integrate sustainable energy resources, it is necessary to have a more active approach to significantly reduce fossil fuel consumption. This was because, after the Five-fuel policy of diversification was introduced in the eighth Malaysian Plan (2001 to 2005), the government intended to achieve a 5\% energy mix of RE by 2015 [19,20]. However, Malaysia's RE pace of development is rather poor and its current estimated energy mix contribution of roughly $1 \%$ has failed to achieve its RE aim set in the eighth Malaysian Plan [21]. At the moment, the cumulative capacity installed for the commissioned RE project amounts to $533.65 \mathrm{MW}$ mainly for solar (352.71 MW), followed by biomass (96.80 MW), biogas (53.84 MW) and small-hydro (30.30 MW), as described in Table 1 [22]. Despite the slow development progress in RE, RE is still assuming the complementary role of fossil fuels because of factors such as intermittent output, location and advancement in technology [21]. The average annual production of authorized RE systems rose from $143.06 \mathrm{kMWh}$ in 2012 to $983.82 \mathrm{kMWh}$ in 2017, which indicates a good development with respect to RE sources in Malaysia, as seen in Figure 4 [23]. Additionally, for the first large-scale solar (LSS) project in Malaysia, based in Kuala Langat in Selangor, Tenaga Nasional Berhad (TNB) has obtained financing for RM 339 million [24]. The project is projected to produce $50 \mathrm{MW}$ of electricity and send it to the national grid. The LSS currently supplies 73.2 MW of power to the national grid, exceeding the original goal of $50 \mathrm{MW}$ [25]. The government could use this LSS project as a stimulus to achieve the planned $9 \%$ contribution of RE into the energy mix by 2020 [20].

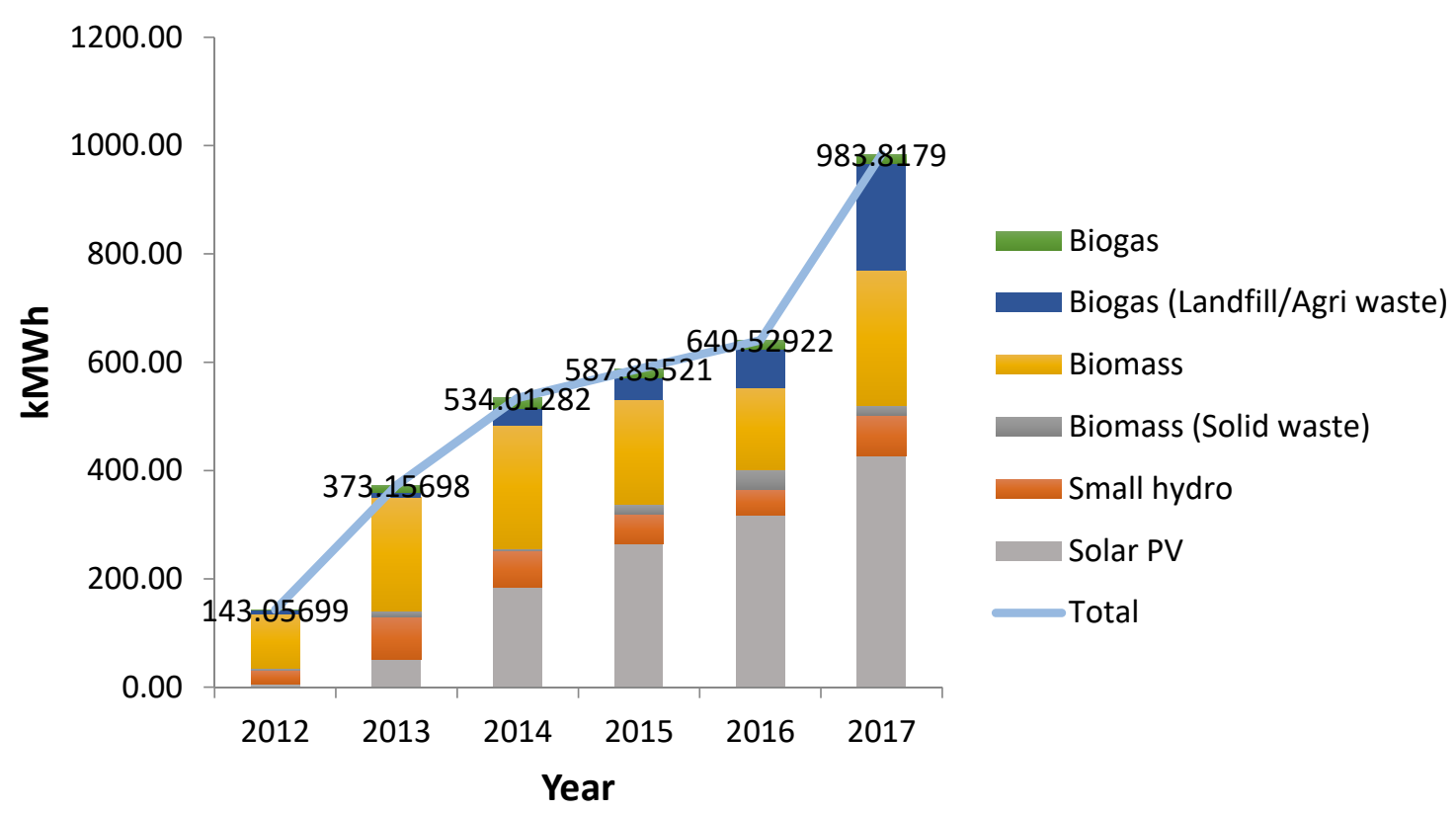

Figure 4. Annual power generation (kMWh) of commissioned RE installations (2012-2017) (source: Sustainable Energy Development Authority Malaysia [23]). 
Table 1. Installed Capacity (MW) of Commissioned RE Installations (FiT Program) (source: Sustainable Energy Development Authority Malaysia [22]).

\begin{tabular}{cccccccc}
\hline Year & Biogas & $\begin{array}{c}\text { Biogas } \\
\text { (Landfill/Agri-Waste) }\end{array}$ & Biomass & $\begin{array}{c}\text { Biomass } \\
\text { (Solid Waste) }\end{array}$ & Small Hydro & Solar PV & Total \\
\hline 2012 & 2.00 & 3.16 & 36.90 & 8.90 & 11.70 & 31.54 & 94.20 \\
2013 & 3.38 & 3.20 & 0.00 & 0.00 & 0.00 & 106.99 & 113.57 \\
2014 & 1.10 & 0.00 & 12.50 & 0.00 & 0.00 & 64.89 & 78.49 \\
2015 & 0.00 & 5.40 & 12.00 & 7.00 & 6.60 & 60.30 & 91.29 \\
2016 & 0.00 & 15.46 & 19.50 & 0.00 & 12.00 & 75.35 & 122.31 \\
2017 & 0.00 & 20.14 & 0.00 & 0.00 & 0.00 & 13.65 & 33.79 \\
Cumulative & 6.48 & 47.36 & 80.90 & 15.90 & 30.30 & 352.71 & 533.65 \\
\hline
\end{tabular}

In order to support the use of RE in Malaysia, a hybrid wind-solar renewable energy generation system for the EKOMAR UKM was designed by researchers from Universiti Kebangsaan Malaysia (UKM). The platform for marine research was developed at the UKM through EKOMAR and is located in Kampung Tanjung Resang, Mersing [26]. The combination of $3 \mathrm{~kW}$ photovoltaic (PV) solar panels and $2 \mathrm{~kW}$ wind turbines, as in Figure 5, is used in producing hybrid renewable energy generation. The PV panels are mounted on the top of the EKOMAR building, whereas the wind turbine at the front of the building is facing the sea, shown in Figure 6. Smart energy storage and control devices in the building monitor electricity supply and demand balancing. The solar irradiance, wind speed, wind direction, humidity, and air temperature are also collected. The project's sole objective was to emphasize intelligent energy-saving measures and to show the socio-economic benefits of a nano-grid, standalone wind-solar hybrid system in remote and isolated rural areas. The system can generate $9500 \mathrm{kWh}$ of electricity annually with an average electricity cost of about RM 0.40 , meaning the savings are about RM 3800 per year.

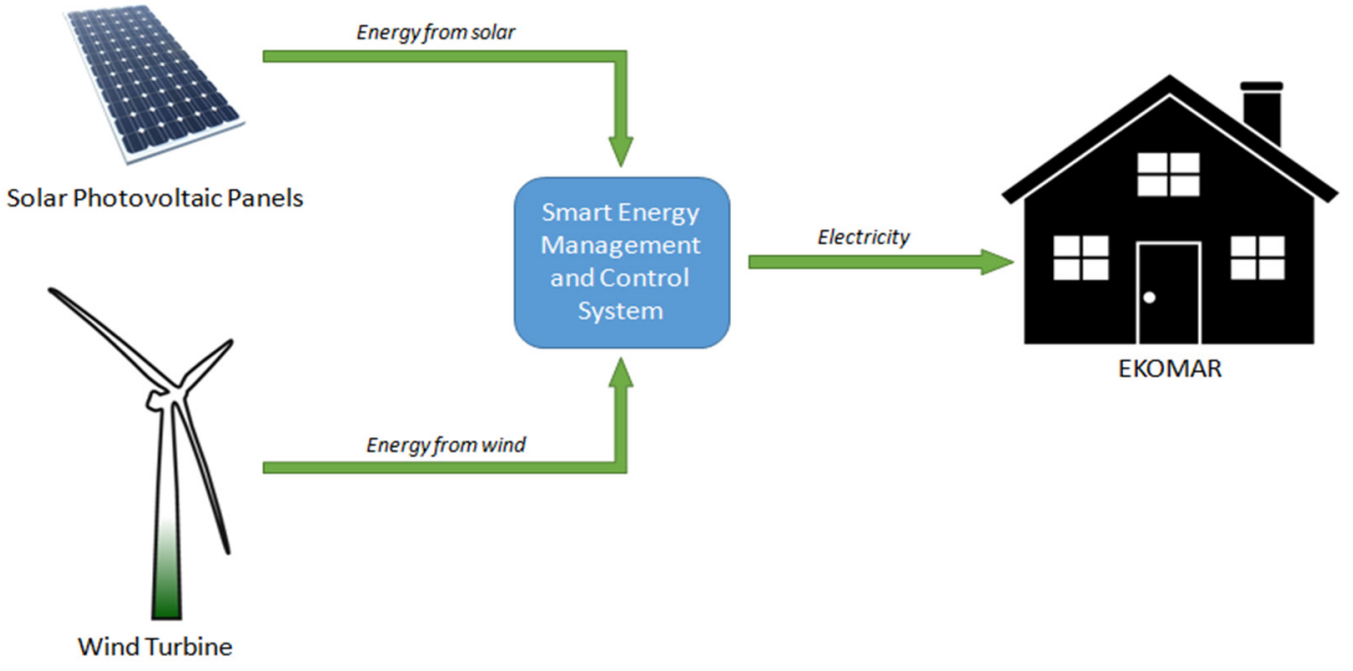

Figure 5. EKOMAR hybrid wind-solar renewable energy generation system.

Malaysia is a tropical country with more than $10 \mathrm{~h}$ of sunshine a day throughout the year [27]. Photovoltaic (PV) panels are used to convert the solar energy into electricity [11]. The great environment in Malaysia is a rather reliable source of energy generation for photovoltaic solar systems [27-29]. An additional 1400 and $1900 \mathrm{kWh} / \mathrm{m}^{2}$ per year [30] have provided solar energy at an annual irradiance mean of $1643 \mathrm{kWh} / \mathrm{m}^{2}$ [31], whereas the average solar insulation is around $5.5 \mathrm{~kW} / \mathrm{m}^{2}$ daily [10]. Wind energy can also be collected in certain parts of Malaysia [32-34]. Basically, wind turbines transform wind energy into a useful form of energy, including electricity [10,11]. The most powerful wind resource for generating energy in Peninsular Malaysia, particularly during the monsoon season, is located in Mersing, as demonstrated by statistical analysis from earlier studies [32,34,35]. The calculated 
average power density at $10 \mathrm{~m}$ above sea level in Mersing is $85.61 \mathrm{~W} / \mathrm{m}^{2}$ [34]. Thus, EKOMAR was selected for the generation system of hybrid wind-solar renewable energy initiative.

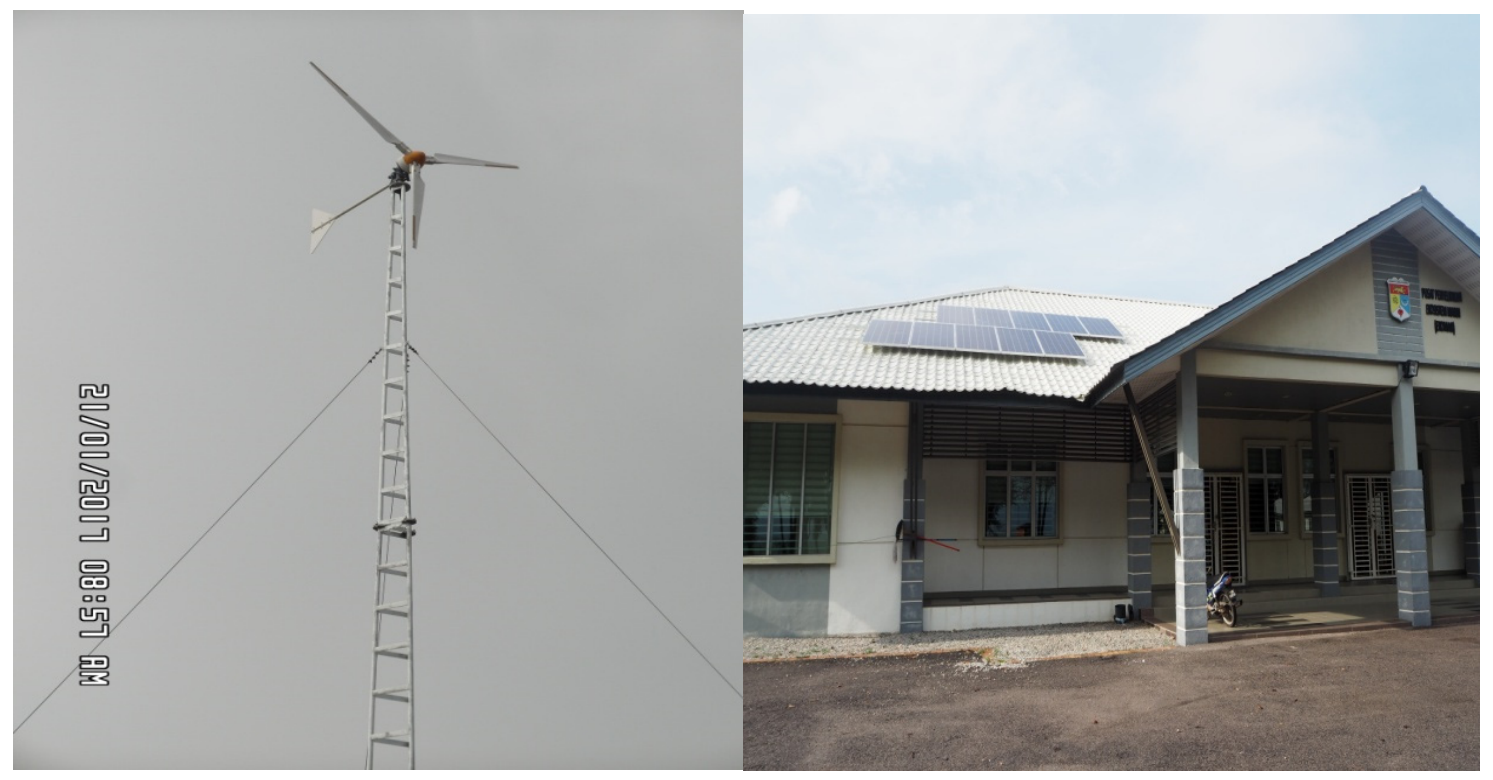

Figure 6. The installed 2-kW wind turbine and 3-kW solar photovoltaic panels at EKOMAR.

The purpose of this study is to evaluate the acceptability of the RE technologies, particularly hybrid wind-solar sustainable RE system installation at EKOMAR among the rural community in Kampung Tanjung Resang, Mersing. Since the rural community usually has a relatively low level of educational background, there are possibilities that the rural community would oppose RE technologies. In this study, the survey was carried out twice both before and after the RE project was implemented at EKOMAR. The RE project at EKOMAR is expected to generate more awareness of RE technologies, especially wind and solar energy, for the residents of Kampung Tanjung Resang. Therefore, it is believed that the awareness of RE technologies among rural residents after the RE project would be increased, as compared to before the RE project.

This article is formulated as follows: in Section 2, the theoretical background of this work is clarified; Section 3 provides a brief introduction to the field of study; the approaches and research design used are addressed in Section 4, whereas the key outcomes of the study are illustrated in Section 5, before and after the implementation of the EKOMAR wind solar standalone RE project; the article is then summarized in Section 6.

\section{Theoretical Background}

The effective implementation of RE technology will lead to a stable enhancement of specific regions by offering a wide range of socio-economic and environmental benefits, such as energy supply diversification, expanded national and rural incentives for growth, the production of the domestic industry and work opportunities [36,37]. Social acceptance of RE is one of the most critical aspects in the successful use of RE technology [38-41]. In fact, perceptions of the public need to be shifted to render the RE system more comprehensive [42]. Besides, Walker stated that one should not underestimate the difficulty of the challenge to gain an awareness of "what the citizens think" and "how attitudes are shaped, modified and created" [38].

For several nations, societal recognition of RE is especially essential to policymakers who push for a quick introduction of RE technology to reduce climate change [43,44]. Wolsink [45] describes RE's social acceptance as "accepting all related participants in a society, which means a much wider and conceptually distinctive context than pure recognition by the public". According to Wüstenhagen et al. [39], the societal acceptance of culture has three separate dimensions: socio-political acceptance; acceptance of the community; 
acceptance of the market. Socio-political acceptance is "public recognition of the media, main actors and decision makers at the broadest, most general stage". Meanwhile, "RE product adoption by customers, buyers, manufacturers and other industry actors" applies to market acceptance. Lastly, acceptance of the community refers to "recognition by local stakeholders, particularly local authorities and residents on RE-technologies."

This paper reflects on the aspect of acceptance of community, which is often called public acceptance. Acceptance of the Community is determined by essential aspects in three areas, including delivery, procedural fairness and the confidence of the community [39]. The basic questions given here are described in all these categories. Distributive fairness- "how will burdens and profits be shared?"; Procedural fairness: "Does all relevant stakeholders have a fair decision-making process in place? to participate"; Community confidence- "Does the local population support the developers and actors' information and intention from beyond the community?".

Many potential reasons for varying degrees of public acceptability on various RE technologies can be found in the literature $[40,42,43,46,47]$. For instance, the literature on public acceptance of RE technologies has been outlined extensively by Devine-Wright [42]. Personal details on age, gender, ethnicity, employment, social-psychological awareness, direct experience, environmental and political views, commitment to location, contextual technology forms, sizes, the hierarchical system and the spatial setting were among the variety of possible explications considered at three rates of analytics. The definitions of Wüstenhagen et al. [39] and Devine-Wright [42] have been clarified in the literature to affect the social recognition of RE technologies [47].

In general, studies on public acceptance of different RE technologies showed little difference where there is a high public acceptance for almost all types of RE [47-53]. However, based on previous studies, for different countries, there are different preferences for different types of RE sources. For example, Hanley and Nevin [54] found that the respondents in North Assynt Estate, Scotland have greater preference for small-scale hydro power, followed by wind farms and biomass schemes. In addition, Borchers et al. [55] discovered that solar energy is the most preferable RE, followed by wind power and biomass for consumers in New Castle County, Delaware (US). In another report, the wind energy has demonstrated a better social acceptability status than solar and geothermal energy in Iran, which was based on indicators and the process of and analytical hierarchy [56].

In Malaysia, studies on public acceptance of RE technology have been done by several researchers as those by Lim and Lam [57], Kardooni et al. [58] and Kardooni et al. [59]. Despite all existing studies, there is still no study focusing on the public acceptance of RE technology among the rural areas. The literature indicates that the usage of RE technology is the strongest solution to rural energy poverty in the remote regions $[35,60]$. Therefore, it is crucial to investigate the public acceptance of RE technologies among rural residents as we can understand their attitudes towards RE technologies, such as their knowledge about RE and their willingness to implement RE technologies. There are possibilities that the rural community would oppose RE technologies, since most of them are poor and have relatively low level of education compared to urban people [61].

Within this article, a field study was carried out on the basis of the wind-solar-independent RE project of EKOMAR in terms of the rural public approval of RE. Two survey sessions were performed before and after the RE venture was carried out to explore the perceptions towards RE technologies among the local communities of Kampung Tanjung Resang. Since most of the rural communities usually have a low level of educational background, the surveys were carried out based on simple design to ensure it was easier for the participants to understand and to answer questions. Through this study, the rural resident's general knowledge, opinions and beliefs of RE technology can be studied, especially on several aspects, including the awareness of rural residents on RE, advantages of RE and potential of RE development in rural regions. Figure 7 shows the variables used to investigate rural residents' attitudes towards RE technology. 


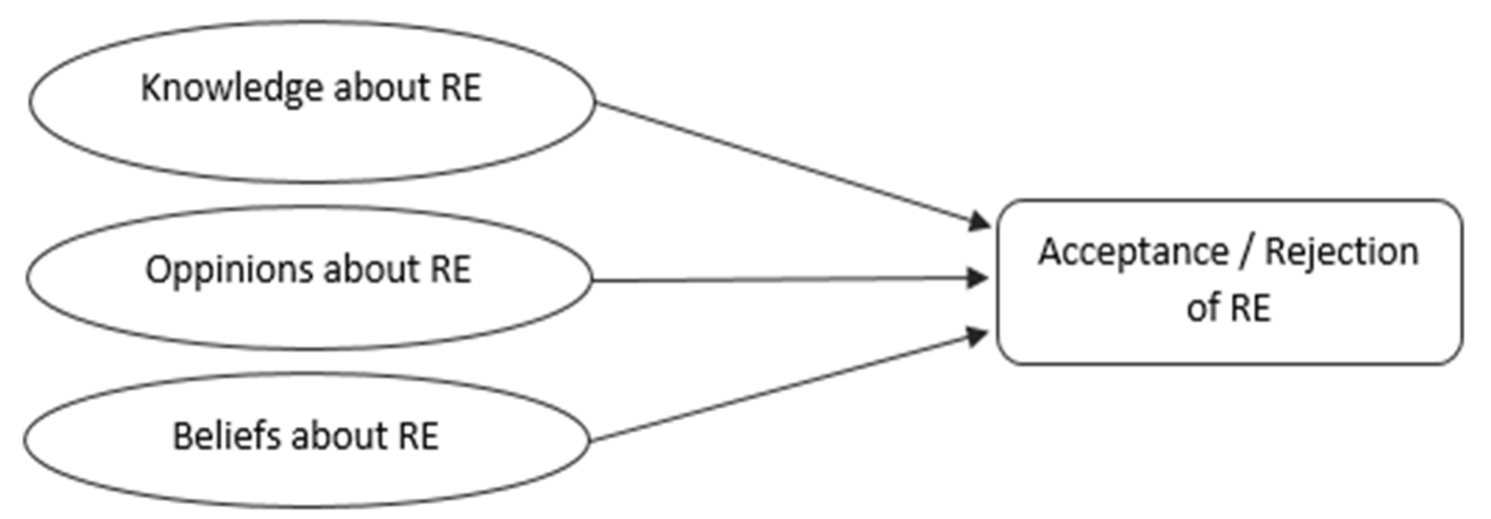

Figure 7. Main variables used to investigate rural residents' attitudes towards RE technologies.

\section{Area of Study}

As can be observed in Figure 8, Kampung Tanjung Resang, Mersing, is a town in Johor, Malaysia, with a land area of about $4.7 \mathrm{~km}^{2}$ or 1170 acres and 200 people living in it, according to the headman of Tanjung Resang. The village is located next to the South China Sea on Malaysia's eastern shore, where most of them are Malay working as fishermen. The village has a beautiful beach overlooking the shore of the Southern China. Close to this village are several well-known travel destinations, such as Air Papan beach, Penyabong beach and Gunung Arong recreational forest. Since Kampung Tanjung Resang is classified as a rural area in Mersing, it therefore presents a significant opportunity to study rural residents' opinions and beliefs regarding RE technologies.

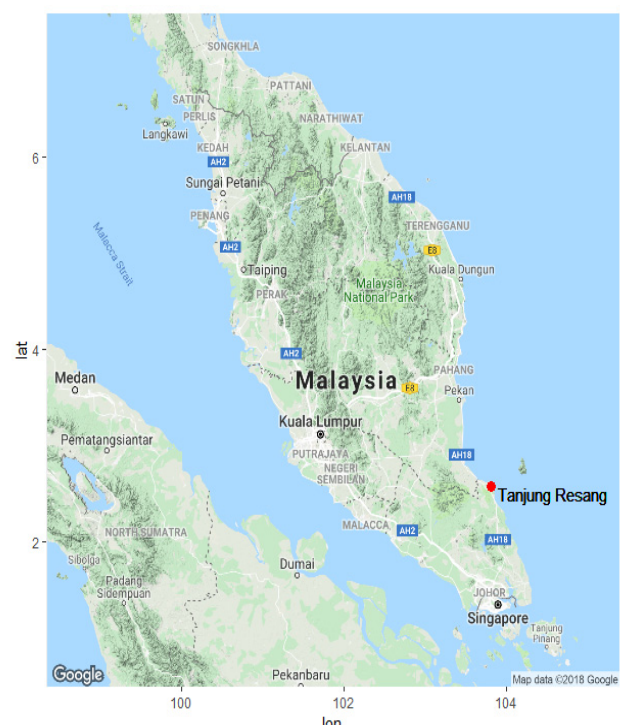

(a)

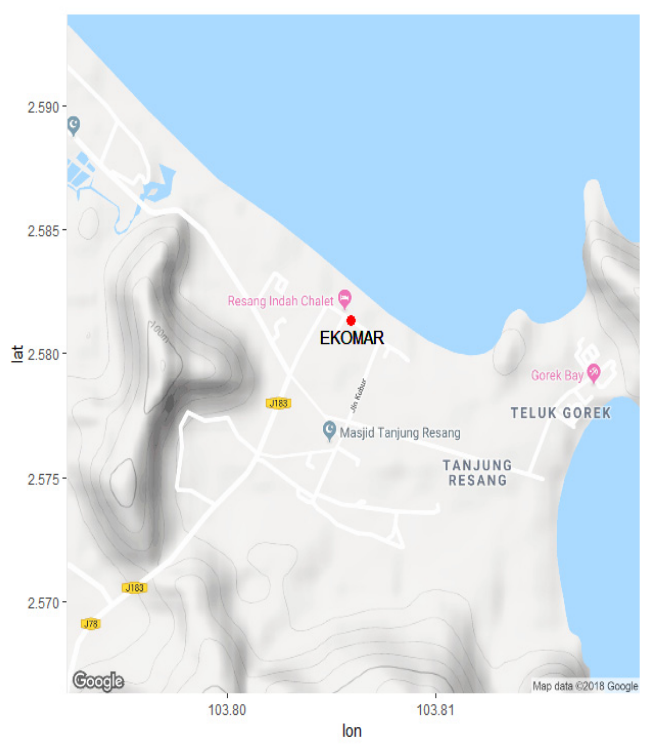

(b)

Figure 8. (a) Map of Malaysia where the red dotted point indicates the location of Kampung Tanjung Resang. (b) Map of Kampung Tanjung Resang where the red dotted point indicates the location of EKOMAR (source: Google [62]).

\section{Methodology}

A survey questionnaire for this study was used to measure the public's attitudes to RE technologies, which consisted of two stages. The first stage was performed before the installation the of hybrid wind-solar renewable energy generation system at EKOMAR and the second phase was done after the deployment of the hybrid wind-solar renewable energy generation facility. 
Many of the questions in both polls were based primarily on solar and wind power for two purposes. Firstly, the hybrid wind solar RE generation device is a part of the RE project built at EKOMAR. The EKOMAR RE project is, therefore, expected to raise awareness for the residents of Kampung Tanjung Resang, Mersing of technologies of RE, particularly of wind and solar energy. Secondly, solar and wind energy are currently likely to be the most advantageous RE technologies in Mersing due to climate and climate factors. Therefore, the views of rural residents on RE technologies, particularly solar and wind energy, can be studied based on surveys conducted at Kampung Tanjung Resang.

\subsection{Survey on EKOMAR Prior to the RE Project}

In the first stage, 64 participants were interviewed. This first survey was performed at EKOMAR in the middle of November 2016 prior to the deployment of hybrid wind-solar renewable energy generation at the beginning of December 2016. Each respondent was randomly selected to minimize the likelihood of bias. In other words, all residents had an equal probability of being chosen as interviewees. The survey was conducted in the form of direct interviews of target respondents. Each question was accompanied by a detailed verbal explanation by the interviewers without considering the respondents' levels of familiarity with RE technologies. An illustration of the RE project at EKOMAR is shown in Figure 5 to provide the definition of wind and solar energy processes and how they work.

The first survey started with information concerning participants' demographic profiles: sex, age, education and residential status. The participants were then asked nine other key questions, which were split into two parts. Part 1 asked questions regarding their awareness of EKOMAR, while Part 2 asked questions regarding RE wind and solar technologies. Such key questions were formulated as "yes" or "no" questions or as questions with multiple choices. The subjects were free to choose more than one answer for multiple choice questions. Table 2 displays all the key questions.

Table 2. Questions for first survey (prior to EKOMAR project implementation).

\begin{tabular}{|c|c|}
\hline Section & Questions/Statements \\
\hline Knowledge and opinion of EKOMAR. & $\begin{array}{l}\text { Do you know about the existence of EKOMAR? } \\
\text { a. Yes b. No } \\
\text { If the answer is "yes", how do you know about EKOMAR? } \\
\text { a. Government office } \\
\text { b. Friends/Family members } \\
\text { c. Newspaper/Media } \\
\text { d. EKOMAR staff } \\
\text { If the answer is "yes", what is the function of EKOMAR? } \\
\text { a. Research center } \\
\text { b. Recreation area/Campgrounds } \\
\text { c. Training center } \\
\text { d. Marine gallery }\end{array}$ \\
\hline $\begin{array}{l}\text { Knowledge and opinion on RE (wind and solar) } \\
\text { and RE projects at EKOMAR. }\end{array}$ & $\begin{array}{l}\text { Do you know about RE, such as wind and solar energy? } \\
\text { a. Yes b. No } \\
\text { Do you think wind and solar energy resources are beneficial to } \\
\text { humankind? } \\
\text { a. Yes b. No } \\
\text { Researchers from UKM plan to generate wind and solar energy at } \\
\text { EKOMAR. Do you know about this RE project? } \\
\text { a. Yes b. No } \\
\text { If the answer is "yes", how do you know about this project? } \\
\text { a. Government office } \\
\text { b. Friends/Family members } \\
\text { c. Newspaper/Media } \\
\text { d. EKOMAR staff } \\
\text { Do you agree that Mersing is a suitable area to develop wind and } \\
\text { solar energy? If yes, please provide a reason. } \\
\text { a. Yes b. No } \\
\text { If this project is successful, would you willing to implement wind } \\
\text { and solar technologies in your home? } \\
\text { a. Yes b. No }\end{array}$ \\
\hline
\end{tabular}




\subsection{The Survey after the RE Project at EKOMAR}

Following the deployment in EKOMAR of the hybrid wind-solar power generation device in early December 2016, the second analysis was carried out in late January 2017. A total of 80 respondents were surveyed in this second phase. The same methodology as the first survey was utilized for the second survey, including direct interviews and random selection of respondents. A detailed explanation of each question and an illustration of the RE project at EKOMAR was provided, even though the RE project had already been initiated at EKOMAR.

The questionnaire posed 13 questions, matching the demographic descriptions of the participants. The questions were split into two parts-the first was based on their awareness and perspectives on EKOMAR's RE initiatives, while the second on wind and solar RE technologies. In the second part of this survey, the first two questions were made identical to those in the earlier survey to determine whether or not the wind and solar energy use at EKOMAR was beneficial in informing local citizens about RE. All questions were structured as "yes" or "no" questions, questions with multiple choices or questions of Likert scale sort. For questions with multiple choices, it was appropriate for respondents to choose more than one response and, for questions with a Likert scale, respondents were asked to grade their information and views on a five-point scale, from "highly disagree" to "highly agree". A five-point Likert scale was used since it has been proven to be less complex and increase the response levels [63]. The key questions for the second survey are listed in Table 3.

Table 3. Questions for second survey (after EKOMAR project implementation).

\begin{tabular}{|c|c|}
\hline Section & Questions/Statements \\
\hline $\begin{array}{l}\text { Knowledge and opinion of RE project } \\
\text { at EKOMAR. }\end{array}$ & $\begin{array}{l}\text { Did you know about the implementation of wind and solar energy } \\
\text { projects at EKOMAR? } \\
\text { a. Yes b. No } \\
\text { If "yes", do you agree with the implementation of RE such as wind and } \\
\text { solar energy? } \\
\text { a. Yes b. No } \\
\text { If "yes", do you agree that RE technologies such as wind and solar do } \\
\text { not obstruct your view? } \\
\begin{array}{ll}\text { a. Yes b. No }\end{array}\end{array}$ \\
\hline $\begin{array}{l}\text { Knowledge and opinions as well as beliefs } \\
\text { about RE technologies (wind and solar). }\end{array}$ & $\begin{array}{l}\text { Do you know about RE such as wind and solar energy? } \\
\text { a. Yes b. No } \\
\text { Do you think wind and solar energy are beneficial to humankind? } \\
\text { a. Yes b. No } \\
\text { In your opinion, what are the advantages of RE technologies? } \\
\text { a. Environmentally friendly/Reduce pollution } \\
\text { b. Save money } \\
\text { c. Promote tourism } \\
\text { The public should have awareness of RE. } \\
\text { 1. Strongly disagree 2. Disagree } 3 \text {. Neutral } 4 \text {. Agree } 5 \text {. Strongly agree } \\
\text { It is important for a community to rely on RE such as wind and } \\
\text { solar energy. } \\
\text { 1. Strongly disagree } 2 \text {. Disagree } 3 \text {. Neutral } 4 \text {. Agree } 5 \text {. Strongly agree } \\
\text { The utilization of RE technologies (wind and solar) should be expanded } \\
\text { throughout Mersing. } \\
\text { 1. Strongly disagree } 2 \text {. Disagree } 3 \text {. Neutral } 4 \text {. Agree } 5 \text {. Strongly agree } \\
\text { RE technologies (wind and solar) should get attention from the } \\
\text { government. } \\
\text { 1. Strongly disagree } 2 \text {. Disagree } 3 \text {. Neutral } 4 \text {. Agree } 5 \text {. Strongly agree } \\
\text { In the future, I will utilize RE technologies such as wind and solar as an } \\
\text { alternative to the existing energy sources. } \\
\text { 1. Strongly disagree } 2 \text {. Disagree } 3 \text {. Neutral } 4 \text {. Agree } 5 \text {. Strongly agree } \\
\text { RE technologies create less environmental damage from pollution. } \\
\text { 1. Strongly disagree } 2 \text {. Disagree } 3 \text {. Neutral } 4 \text {. Agree } 5 \text {. Strongly agree } \\
\text { RE technologies can help increasing the capacity of electricity } \\
\text { generation, especially in rural areas. } \\
\text { 1. Strongly disagree } 2 \text {. Disagree } 3 \text {. Neutral } 4 \text {. Agree } 5 \text {. Strongly agree }\end{array}$ \\
\hline
\end{tabular}




\section{Results and Discussion}

\subsection{Respondent Demographics}

Table 4 displays the demographic profiles of respondents in the first and second surveys. As observed, $56.3 \%$ of respondents were male and $43.7 \%$ were female in both surveys. Most of the respondents were between $26-40$ years of age ( $29.7 \%$ in the first survey and $37.5 \%$ in the second survey) or between $41-60$ years of age (35.9\% in the first survey and $28.7 \%$ in the second survey). There were fewer respondents between 15 and 25 or above 60 years of age in both surveys. The respondents were largely made up of local residents (81.2\% and $93.7 \%$ in the first and second surveys, respectively). Only $18.8 \%$ of respondents in the first survey and $6.3 \%$ of respondents in the second survey were non-local residents. Overall, a majority of respondents had received less than or equal to a lower secondary education $(43.8 \%$ and $50.0 \%$ in the first and second surveys, respectively) or an upper secondary education (50.0\% and $35.0 \%$ in the first and second surveys, respectively). Only a small proportion of the respondents have a diploma or equivalent ( $3.1 \%$ and $13.7 \%$, respectively) or higher degree (3.1\% and $1.3 \%$, respectively), thus indicating a relatively low education level among these rural residents.

Table 4. Respondents' demographic profiles.

\begin{tabular}{cccccc}
\hline \multirow{2}{*}{ Variables } & \multirow{2}{*}{ Options } & \multicolumn{2}{c}{ First Survey } & \multicolumn{2}{c}{ Second Survey } \\
\cline { 2 - 6 } & & Count & Percentage (\%) & Count & Percentage (\%) \\
\hline \multirow{2}{*}{ Gender } & Male & 36 & 56.3 & 45 & 56.3 \\
& Female & 28 & 43.7 & 35 & 43.7 \\
\hline \multirow{3}{*}{ Age } & $15-25$ & 12 & 18.8 & 13 & 16.3 \\
& $26-40$ & 19 & 29.7 & 30 & 37.5 \\
& $41-60$ & 23 & 35.9 & 31 & 38.7 \\
\hline \multirow{3}{*}{ Education } & $>60$ & 10 & 15.6 & 6 & 7.5 \\
& Lower secondary school or below & 28 & 43.8 & 40 & 50.0 \\
& Upper secondary school & 32 & 50.0 & 28 & 35.0 \\
& Diploma or equivalent & 2 & 3.1 & 11 & 13.7 \\
\multirow{2}{*}{ Residency status } & Degree or above & 2 & 3.1 & 1 & 1.3 \\
\hline
\end{tabular}

\subsection{Data Analysis for the First Survey}

Most of the respondents (79.9\%) were aware of the existence of EKOMAR in Kampung Tanjung Resang. As shown in Figure 9, among these respondents, 58.6\% knew about EKOMAR through friends or family members, $34.5 \%$ through EKOMAR staff, $5.2 \%$ through the government office and $1.7 \%$ through newspaper or media. Those respondents who knew about EKOMAR were also asked about the function of EKOMAR (Figure 9). Of the 61 answers, 65.5\% identified EKOMAR as a research center, 21.3\% identified EKOMAR as a training center, while 6.6\% identified EKOMAR as marine gallery or a recreation and campground area. Thus, more than half of the respondents $(65.5 \%)$ who knew about EKOMAR correctly identified the main function of EKOMAR, likely because they were aware of the research activities conducted at EKOMAR.

More than half (54.7\%) were aware of RE, as seen in Figure 10, whereas 45.3\% understood nothing about RE, including wind and solar energy. The cause of why almost half of respondents did not know about RE could be attributed to their lack of higher education. Increasing awareness, knowledge, skills and values needed to build a sustainable future is a key factor for higher education [64]. Furthermore, Stephens et al. [65] mentioned that higher education may be an instrument for shifting the path for sustainable growth in society more rapidly. In total, $89.1 \%$ of those interviewed believed that RE technology, including wind and solar energy would support humanity after a clarification of RE technologies presented. This was a positive indication of RE developments, including wind and solar energy systems being most definitely accepted by the residents of Kampung Tanjung Resang. 


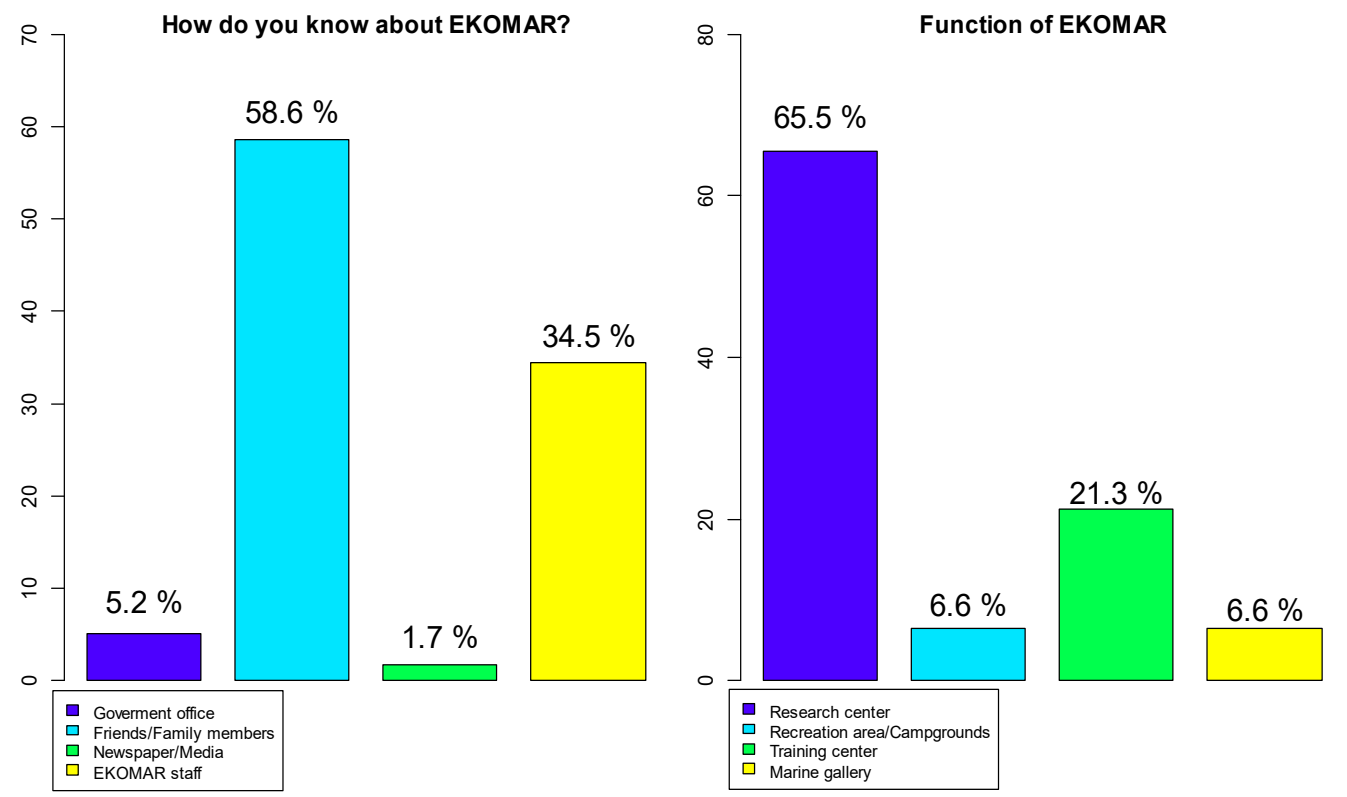

Figure 9. How the respondents find out about EKOMAR and respondents' answers to the function of EKOMAR.

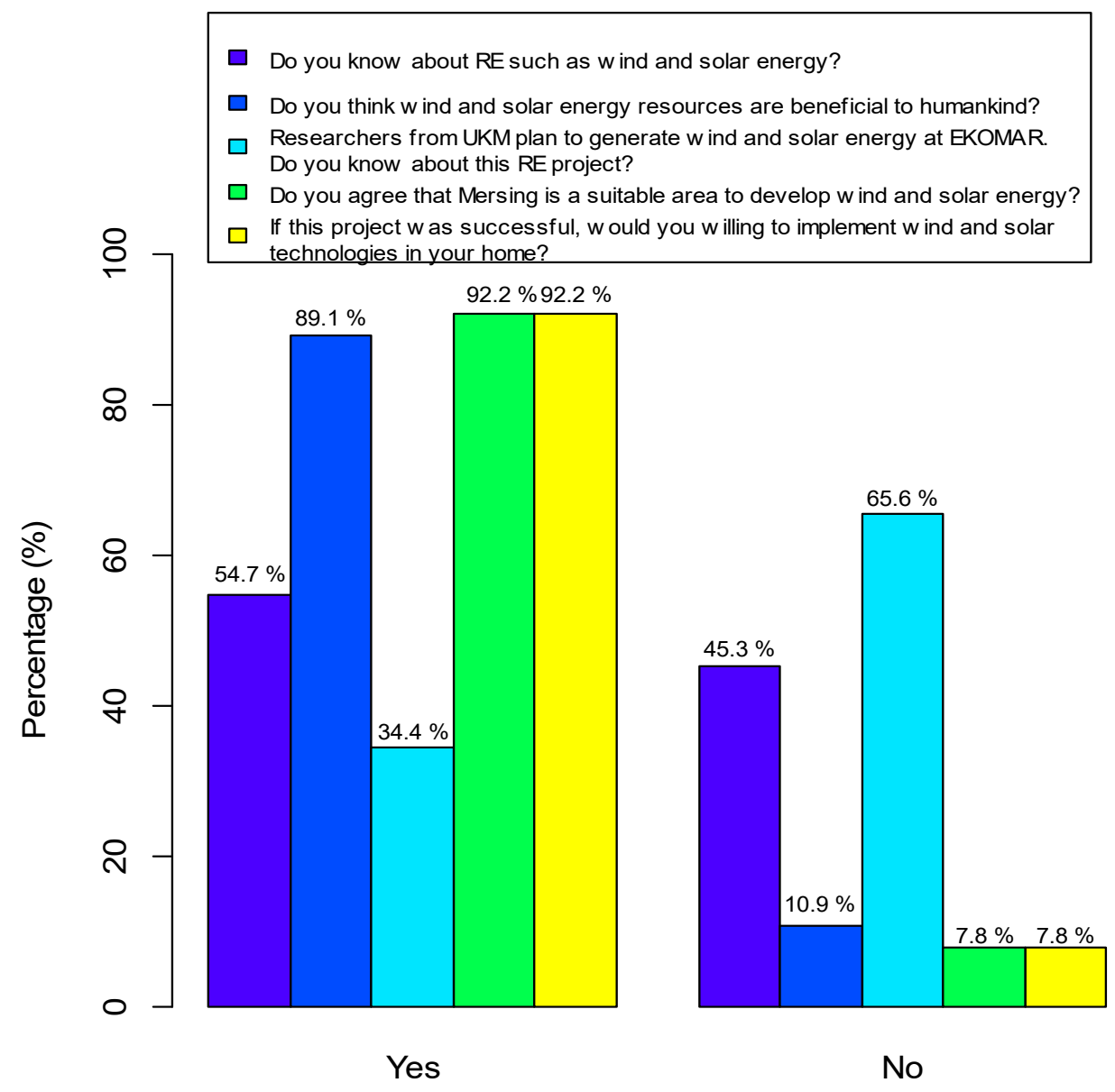

Figure 10. Respondents' answers to "Yes" or "No" questions in Survey 1. 
The participants were also asked about the RE project, in which EKOMAR would install $3 \mathrm{~kW}$ of photovoltaic solar panels and a 2-kW wind turbine, as Figure 5 shows. Only $34.4 \%$ of the participants knew of this initiative, as seen in Figure 10, while 62.5\% learned the of project from EKOMAR workers and $37.5 \%$ from acquaintances or relatives (Figure 11). In the meantime, $65.6 \%$ of those who remained did not learn about EKOMAR's RE initiative. So, while the headman of Kampung Tanjung Resang had made an announcement at the village committee meeting, most of them did not know about the RE initiative. It was estimated that this result was because EKOMAR had not yet installed the wind turbine and solar panels.

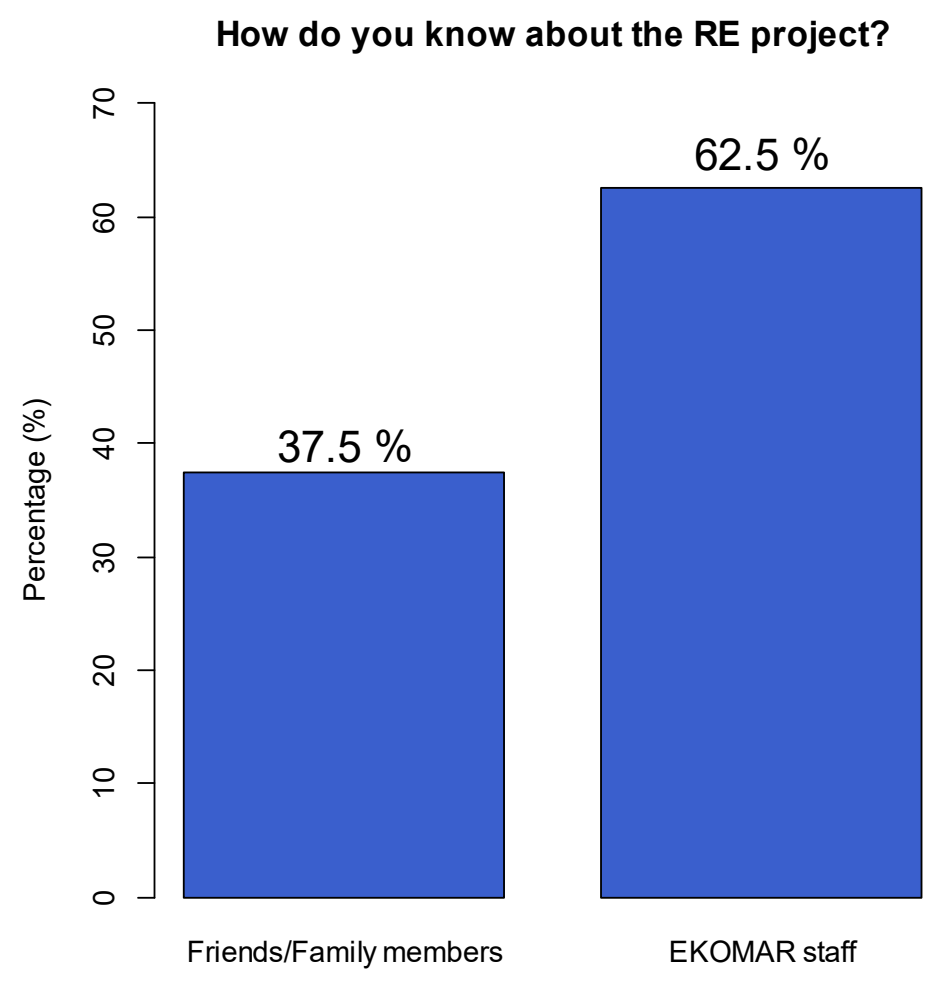

Figure 11. How respondents found out about the RE project at EKOMAR (Survey 1).

The second after a short clarification about how wind and solar energy are made, a majority (92.2\%) of participants agreed-although the remaining 7.8\% disagreed-that Mersing was a good place for the production about RE technologies, including wind and solar power. Just a few of those decided that Mersing could be suitable for the production of wind and solar resources were able to give their reasons. Table 5 lists some of their comments. It is clear from Table 5 that, while most respondents did not receive higher education, some could reasonably answer the question as to why Mersing is perhaps a preferred region for developing RE technologies, in particular wind energy technologies. The respondents were also familiar with the atmosphere and weather of Mersing as they are the residents of Mersing city. Mersing has a considerable wind energy capacity, especially during the monsoon season, which has a strong wind-generating potential $[32,34,35]$. The participants were also questioned if they were prepared to incorporate wind and solar energy systems in their households. Most participants (92.2\%) agreed to implement these two RE approaches, as can be seen in Figure 10. Most of them (89.1\%) agreed that wind and solar energy are beneficial to humans and welcomed the establishment of RE technologies in Kampung Tanjung Resang. As a whole, this study sample responded favorably to RE options, including wind and solar, in Kampung Tanjung Resang. Following the deployment of wind turbines and solar panels at EKOMAR, the second survey was done to further evaluate the residents' expectations, views and opinions. 
Table 5. Reasons why Mersing is a suitable region for wind and solar energy development.

\begin{tabular}{lc}
\hline Comments & No. of Comments \\
\hline "Mersing is one of several suitable regions" & 12 \\
"Mersing is a windy region" & 7 \\
"Mersing is near the beach" & 5 \\
"The Mersing region has strong winds" & 11 \\
\hline
\end{tabular}

\subsection{Data Analysis for the Second Survey}

The second survey was followed by a total of 80 responses. Many of the participants (91.2\%) understood the deployment of the EKOMAR's wind and solar energy program, while the remaining $8.8 \%$ did not realize the RE initiative, as Figure 12 indicates. The deployment of both RE technologies was accepted by all participants $(100 \%)$, who recognized the deployment of the wind turbine and solar panels at EKOMAR. Furthermore, $94.5 \%$ accepted that the wind and solar panel project did not conflict with their opinions for those who were informed of deployment. The answers provided by the participants to those three questions gave this study an initial interpretation of how they support the proposal. Many interviewees acknowledged the use of wind and solar energy. The installation of wind and solar energy systems on EKOMAR seemed a valuable proof of how RE technologies generate energy.

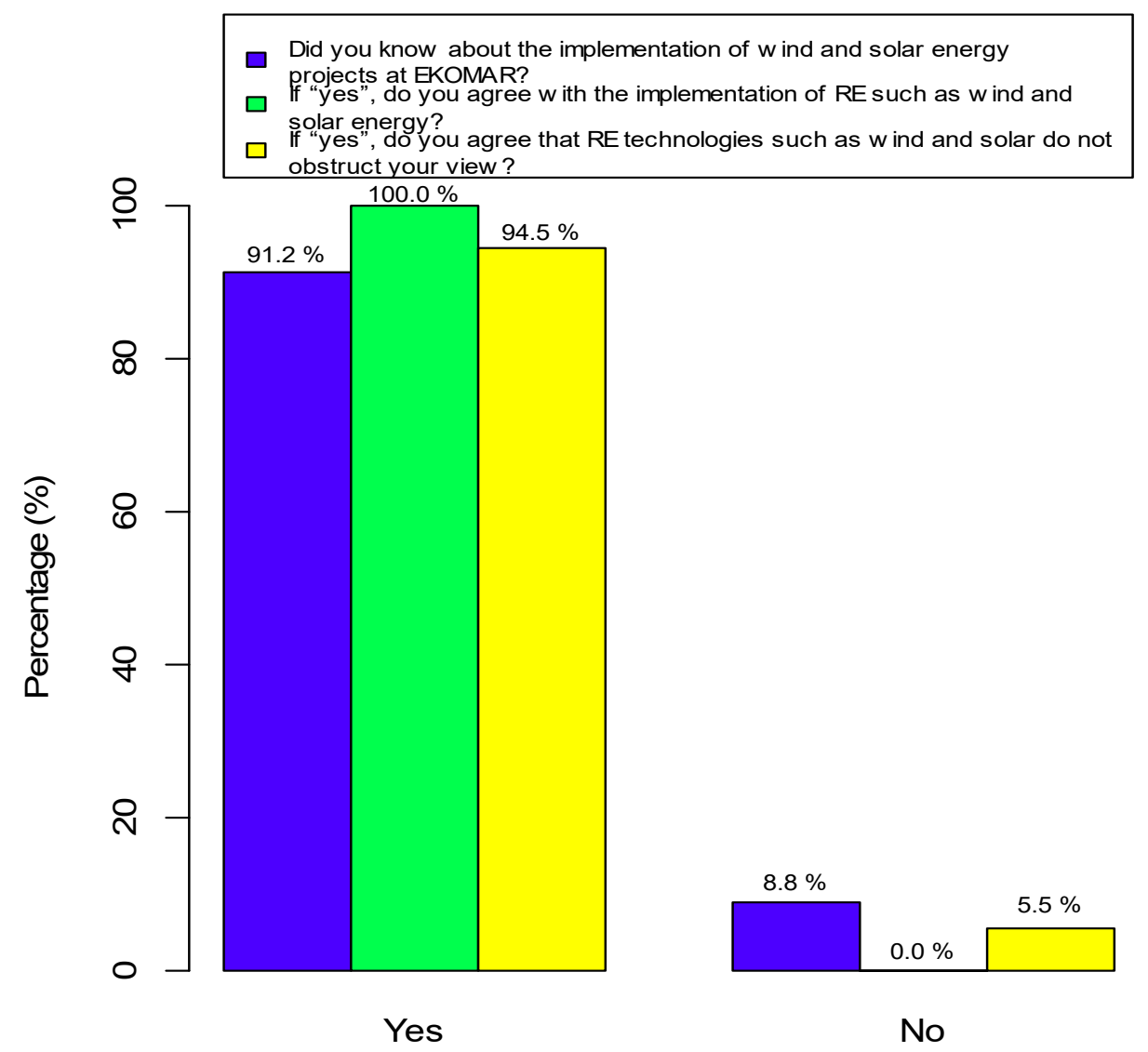

Figure 12. Respondents' answers to "Yes" or "No" questions in Survey 2.

As described above, in the second part, the first two questions were intended to examine the general awareness of participants of RE before and after the wind turbine and solar panels were built. Following the introduction of these two technologies at EKOMAR, almost every respondent (96.2\%) was now informed of RE technologies, especially wind and solar energy. Compared to the first sample figures with just $54.7 \%$ awareness of such developments, there was a substantial rise in general awareness (statistically 
relevant at $95 \%$ ). Further, $98.8 \%$ of surveys reported that the benefits of wind and solar power were agreed by the participants, showing a $9.7 \%$ greater rate than that of the first survey, as demonstrated in Figure 13. Both figures indicate that the second sample increased and can be traced to $91.2 \%$ of participants who became aware about the deployment of RE at EKOMAR. Thus, it can be summarized that wind and solar energy implementation at EKOMAR has played a major role in spreading the awareness of RE among local residents, particularly of wind and solar energy.
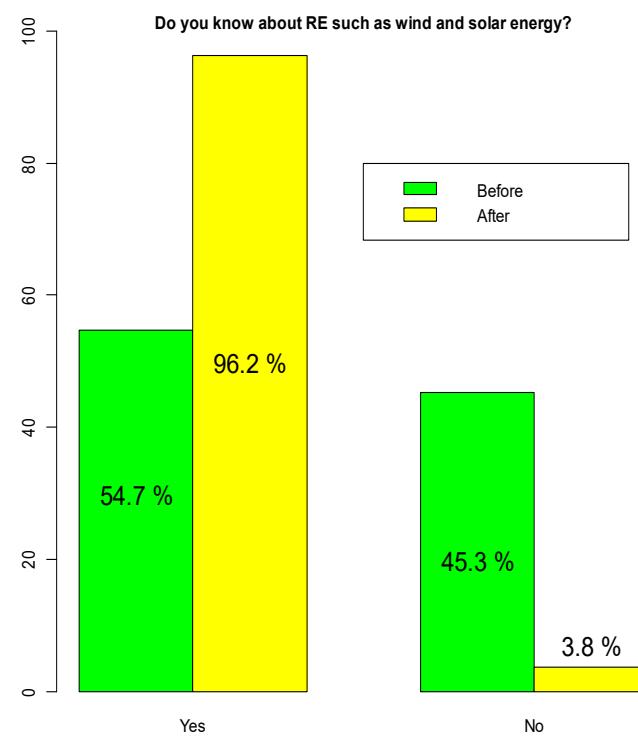

Figure 13. Respondents' general knowledge of RE before and after RE implementation at EKOMAR.

Consequently, questions regarding the benefits of RE technologies, such as wind and solar resources, were asked to the participants. As seen in Figure 14, participants accepted that RE innovations were "environmentally sustainable or pollution-controlled", with $68.1 \%$ of the 91 votes indicating that the disparity between fossil fuels and RE were commonly recognized among the participants. As stated earlier, increased fossil-based energy utilization will lead to increased environmental issues, such as GHG emissions, especially $\mathrm{CO}_{2}$ and GHG, which indirectly cause increased climate change and global warming. Therefore, the use of RE technology, such as wind and solar energy, is a great option over conventional generation of electricity as it produces renewable energy. Optimizing the usage of such sources minimizes environmental effects, creates minimal secondary waste and is beneficial for the economic and social needs of today and in future [11].

Several respondents ( $18.7 \%$ of votes) chose "save money" as their answer for the benefits of using RE technologies, as can be seen in Figure 14. It could be because, as rural citizens with a greater deprivation, it is hard for them to pay electricity bills with comparatively small incomes [66]. Indeed, it was projected that the nation could save RM 5 billion over a span of 5 years by utilizing just $5 \%$ RE in the energy mix [19]. In addition, Weigt [67] found that wind energy generation has cost-saving potential for electricity production. Hence, the utilization of RE technologies to produce energy could help the public and government in reducing expenses.

Figure 14 displays the remaining 13.2\% votes, indicating that RE technology could serve as a tool for "tourism promotion." Many locals suggested that utilizing wind and solar energy to incorporate RE systems in this area might boost tourism by rendering a sustainable destination and generating sustainable business opportunities as the beach of Kampung Tanjung Resang faces the South China Sea in a wonderful angle. The positive impacts of RE on tourism have been discussed in many works. One of them is that the implementation of RE may actually help to grow the tourism industry at a certain tourism destination where RE infrastructures may become an essential tourist attraction to that area. For example, several studies have suggested that wind farms can be the reason for tourist attraction to a certain area [68-72]. This indicates that the attractiveness of wind landscapes is the most crucial aspect that influences tourist 
attraction [69-72]. In other words, the installed wind turbines need to be fit well to the existing landscape to be attractive and accepted by the society. On the contrary, if the installed wind turbines make the existing landscape rather unattractive where the place of attachment of wind turbines is not suitable, it would bring negative visual effects on the landscape and consequently induce negative effects on the acceptance of wind farm landscapes and tourism demand [73-76]. On top of that, the increasing energy demand in the tourism industry could create an opportunity for RE to contribute to the energy mix [72]. The implementation of $\mathrm{RE}$ in the tourism industry may offer a sustainable development at a particular tourism destination by improving energy efficiency and reducing environmental effect and pollution [77,78]. Therefore, besides helping to meet the energy needs in the tourism industry, RE could also help in improving the quality of environment, as this aspect had a significant impact on tourism satisfaction [79,80].

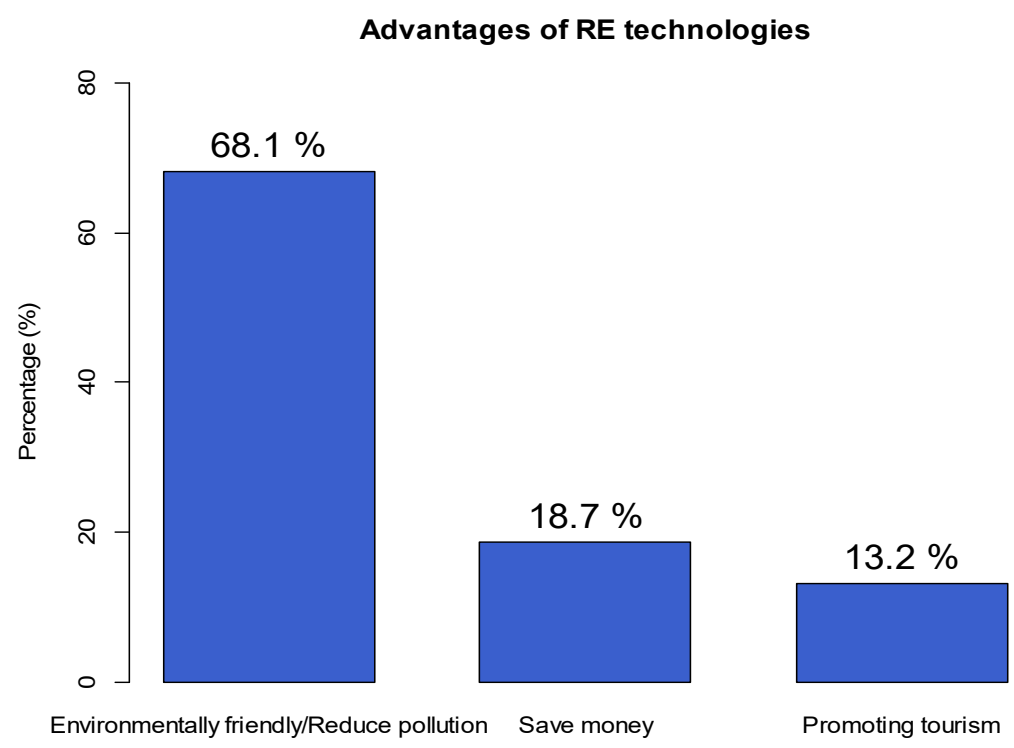

Figure 14. Response of the participants on the benefits of RE (wind and solar) technologies.

Figure 15 illustrates that participants were also questioned if RE should be widely informed to the public. In total, $45 \%$ of participants agreed strongly, followed by $51 \%$ who agreed, $3 \%$ who disagreed and $1.0 \%$ who strongly disagreed, respectively. Most respondents stated that the general public should be informed of RE. The participants may have realized the importance of education to comprehend certain concepts, since most of them have received no higher education. Obviously, RE is important to understand, since this type of energy is considered a clean energy source and an option to existing energy sources based on fossils. In addition, Zakhidov [81] argued that the implementation of the RE program would allow energy efficiency and organic fuel economy to be improved, local energy and water supply issues to be solved, living standards to be increased and work opportunities to local people to be improved, besides the sustainable growth of remote areas in the desert and mountain regions to be assured and solutions to be introduced. Therefore, the public should recognize the definition of RE technology in particular as it is still in an early phase of implementation in Malaysia.

With regard to the public dependence upon RE, about $39.0 \%$ of participants strongly agreed on the need to focus on RE energy, whereas $54.0 \%$ others agreed, $6.0 \%$ were neutral and $1.0 \%$ strongly disagreed. This may have been because of the knowledge obtained from EKOMAR's RE project that RE energy is produced from natural and non-exhaustive sources. As a consequence, roughly $39.0 \%$ of the respondents agreed strongly, $55 \%$ agreed, $5.0 \%$ were neutral and only $1.0 \%$ strongly disagreed that RE would, as seen in Figure 15, act as an option for current energy sources in future. This implies that most participants are open to a prosperous future provided by the use of RE technologies. 


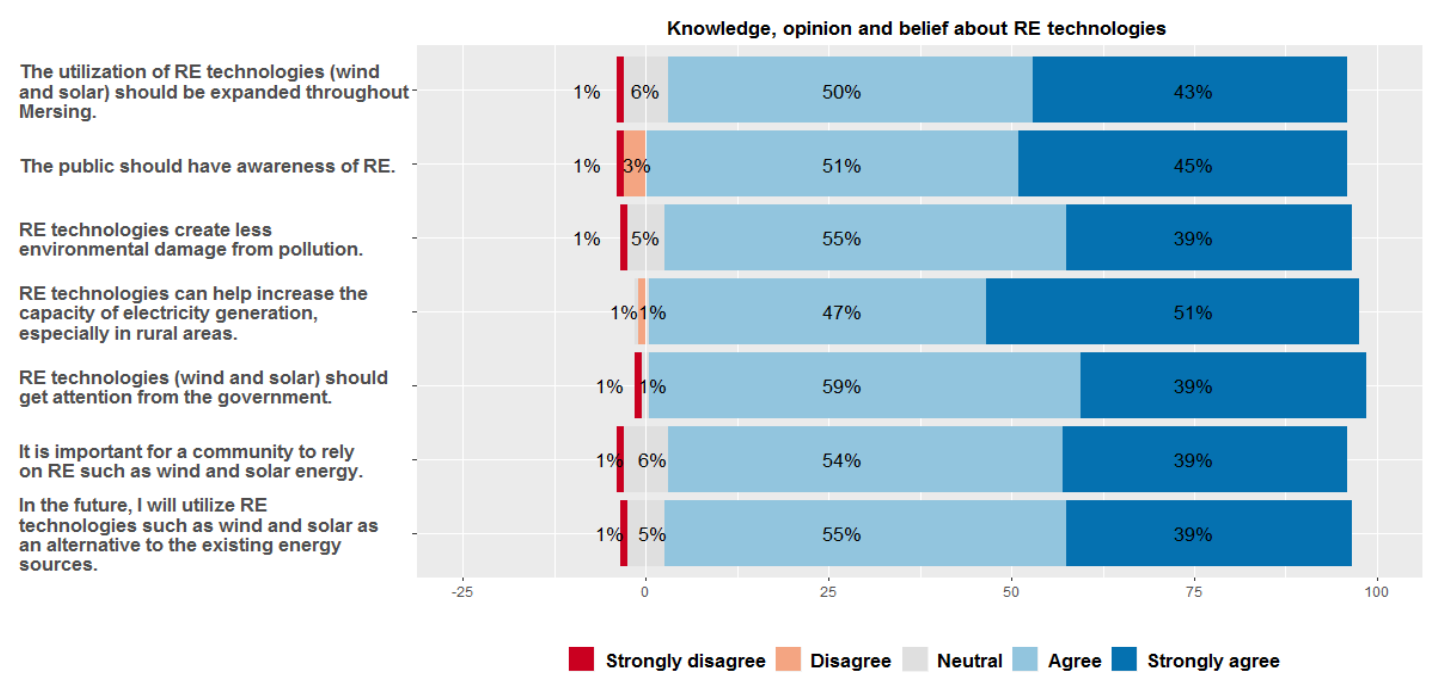

Figure 15. Respondents' knowledge and opinions of and beliefs about RE technologies.

Once questioned if the use of RE technology, such as wind and solar, should be applied to the entire Mersing area, roughly $43.0 \%$ agreed strongly, $50.0 \%$ agreed, $6.0 \%$ was neutral and just $1.0 \%$ strongly disagreed. This indicates a huge number of participants who welcomed Mersing's usage of RE technologies. Mersing is a popular region for wind energy use in Peninsular Malaysia, as previously mentioned. There are also no barriers for the development of solar energy since Malaysia receives an abundance (more than $10 \mathrm{~h}$ per day) of sunshine throughout the year. In addition, the location of Mersing near the South China Sea also makes it a viable candidate for marine renewable energy (MRE) implementation, including wave energy [82]. Therefore, Mersing is well suited for the implementation of both wind and solar energy and has the potential for MRE implementation.

It was found in this study that $39 \%$ of participants strongly agreed, $55 \%$ agreed, $5 \%$ were neutral and $1 \%$ strongly disagreed with the concept of environmental effects and emissions reduction through the introduction of RE technologies. This finding was compatible with their reactions to the key benefits of RE systems by accepting that RE is a system that values the climate. This shows that most participants are aware of the primary objective of developing sustainable energy through RE technologies. Environmental pollution, including air pollution, is a big problem faced by all the countries in the world and has been increasing steadily since the beginning of industrialization era [83]. The ability of RE sources to have null or close to zero air pollution of energy is, therefore, the solution to this issue [11].

The participants were questioned if RE technology could aid an increase in electricity generation efficiency, especially in rural areas. Around $51 \%$ of participants agreed strongly, $47 \%$ agreed, $1 \%$ was neutral and $1 \%$ disagreed with the statement. This result indicates that respondents assumed that the use of RE technology will lead to supplying rural residents with adequate electricity. The general deprivation in developed countries is compounded by energy poorness and electricity shortage in rural areas [35]. Considering the high delivery costs and associated lack of transport, grid power supply is not commercially feasible in rural areas [35]. Apparently, this issue can be solved by the deployment of RE technologies. For villages without electricity, particularly in Malaysia, Fadaeneejad et al. [60] found that rural electrification utilizing hybrid renewable energy systems (HERS) was a viable solution. HERS is a combination of a number of RE sources in which a single system is formed [60]. Thus, EKOMAR used the HERS concept for its electricity generation.

After that, about $39 \%$ of participants strongly agreed, $59 \%$ agreed, $1 \%$ was neutral and $1 \%$ strongly disagreed with the notion that wind and solar energy from RE innovations should obtain the Malaysian government's focus. This might be because of RE's power source capacity in supplying electricity across remote regions, in particular. As mentioned previously, some actions have been undertaken by the Malaysian government, such as RE policy creation, RE program development and RE incentives. According to SEDA, the Malaysian government's target is to achieve $21.4 \mathrm{GW}$ of RE production by 
2050, which would contribute to $73 \%$ of the energy mix [84]. With this goal, an estimated 145.1 million tons of cumulative $\mathrm{CO}_{2}$ emissions would be avoided by 2030 [85].

To investigate in more detail, the Likert scale items are divided into two groups. The correlation between the items in these two group was studied. The first group was about awareness and knowledge of RE, which includes: "the public should have awareness of RE", "it is important for a community to rely on RE such as wind and solar energy", "RE technologies create less environmental damage from pollution" and "RE technologies can help increase the capacity of electricity generation, especially in rural areas". The second group is about desire and acceptance of RE, which consists of: "RE technologies (wind and solar) should get attention from the government", "the utilization of RE technologies (wind and solar) should be expanded throughout Mersing" and "in the future, I will utilize RE technologies such as wind and solar as an alternative to the existing energy sources". Figure 16 displays the correlation between items of first group ( $x$-axis) and second group ( $y$-axis). Based on Figure 16, it can be observed that the items of knowledge and awareness of RE were positively correlated with the items of desire and acceptance of RE. To be more specific, the resulting positive correlation between the items in the first group and the second group is due to the participants' agreements on each question, as shown in Figure 15. Based on this result, it can be concluded that the knowledge and awareness of $\mathrm{RE}$ are important aspects to ensure the community agree and have a desire to implement the RE.

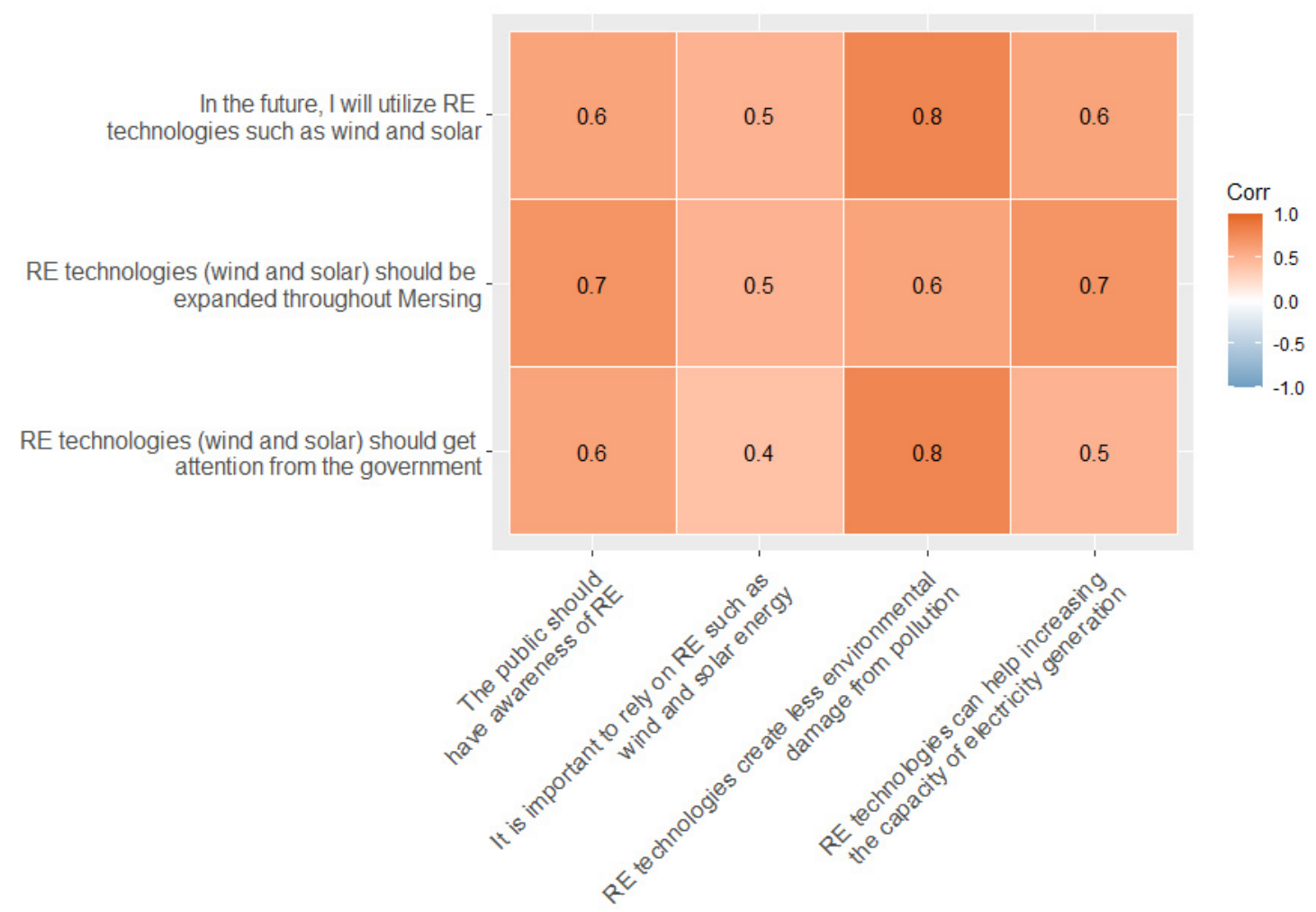

Figure 16. Correlation between items in knowledge and awareness of RE and desire and acceptance of RE.

To support the result of the correlation, the Mann-Whitney $U$ test was applied to determine whether the items in the first group and second group have identical data distribution. The result, based on $p$-value of the Mann-Whitney U test, is shown in Figure 17. Overall, it can be seen that all $p$-values are greater than 0.05 , indicating that all items in the first group and second group have identical data distribution. From this test, it appears that the participants tended to have similar agreement with the items in the first group and second group. Thus, this result further supports the claim that the knowledge and awareness of RE are important aspects to ensure the acceptance of RE. 


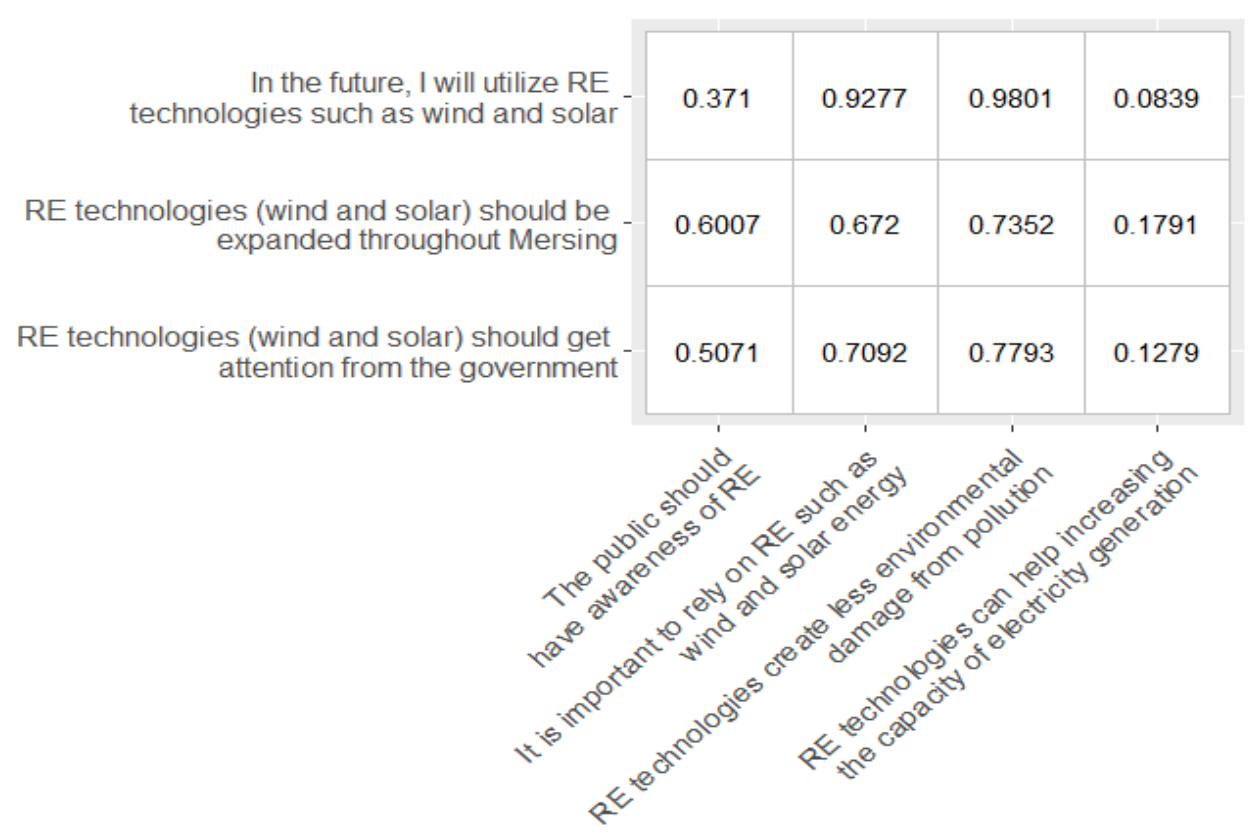

Figure 17. The Mann-Whitney U test ( $p$-value) between the items in knowledge and awareness of RE and desire and acceptance of RE.

\section{Conclusions and Policy Implications}

The view of the public on wind and solar resources is a big obstacle to the growth of RE technology in Malaysia. The goal of this research is to assess RE technologies in Kampung Tanjung Resang, Mersing, in terms of rural public acceptance. A survey was carried out by this study both before and after the wind PV hybrid device was installed. On the basis of this study, it was discovered that most of those interviewed were positive and accepted RE technologies. The overall results showed that residents appreciated the application of RE in remote regions and were convinced of the RE development potential as an option for current energy in remote areas, specifically Mersing. This study includes some recommendations for the goal or plan in the implementation of renewable energy across remote regions to explore general approval of renewable energy deployment in rural locations.

Based on this study, the following policy recommendations are suggested:

(a) The promotion of RE technologies is a crucial step before the implementation of these technologies and should be done properly, particularly in remote regions, to enhance the awareness and knowledge of RE technologies among the rural public. This is because the rural residents usually have a relatively low awareness and knowledge of RE technologies, due to a relatively low educational background. The knowledge of RE technology will therefore be increased as they recognize the technology, know its true benefits and comprehend the objective and environmental value of the technology, besides appreciating its functions. In the sense of learning activities at all stages, educational programs on ER should be introduced and organized as education is one of the most effective forms of getting input into RE technology. Nevertheless, focus should be put on the learning, descriptive, investigative and creative execution of RE education [86]. RE education indeed plays a key role in the growth of a sustainable society. Consciousness of and concern within communities for RE technology should be provided to increase public awareness of various forms of RE energy as alternatives to the current energy to deepen the public trust in the implementation of RE technologies, as well as to build practical principles and social attitudes towards using RE sources [86-89]. As in Malaysia at the moment, RE education is a relatively new field and this program has been offered in formal education at university level, such as in Universiti Malaya (master of renewable energy). However, it is pertinent to include RE education 
programs in any level of education to ensure public understanding towards RE technologies and that sources can be improved for sustainable development in Malaysia.

(b) The implementation of RE technologies is the sustainable solution to address energy poverty and lack-of-electricity issues in rural areas. This is supported by Fadaeneejad et al. [60], mentioning that, in recent years, rural electrification using hybrid renewable energy systems is a reliable solution for villages that have no electricity. The proportion of rural electrification in the Peninsular Malaysia is high in over 90\% with assessable grid connections. In 2001, a Feed-in-Tariff (FiT) Act was adopted by the Malaysia government and employed in FiT RE payment as an established incentive structure for the implementation of RE under the state law. Domestic electricity utilities are required to buy renewable electricity at surplus government market prices. The increased costs tend to reduce RE suppliers' expense drawbacks. Specific forms of RE electricity generation may have different rates.

Presently, a total of $530 \mathrm{MW}$ of RE has been connected to the grid with solar PV, providing almost $300 \mathrm{MW}$ of the RE connected to the grid (Figure 18). Wind energy can be connected to the grid; nevertheless, using the FiT mechanism, it is possible to initiate any RE project in rural areas where there is a potential of wind energy to exist, such as in Mersing.

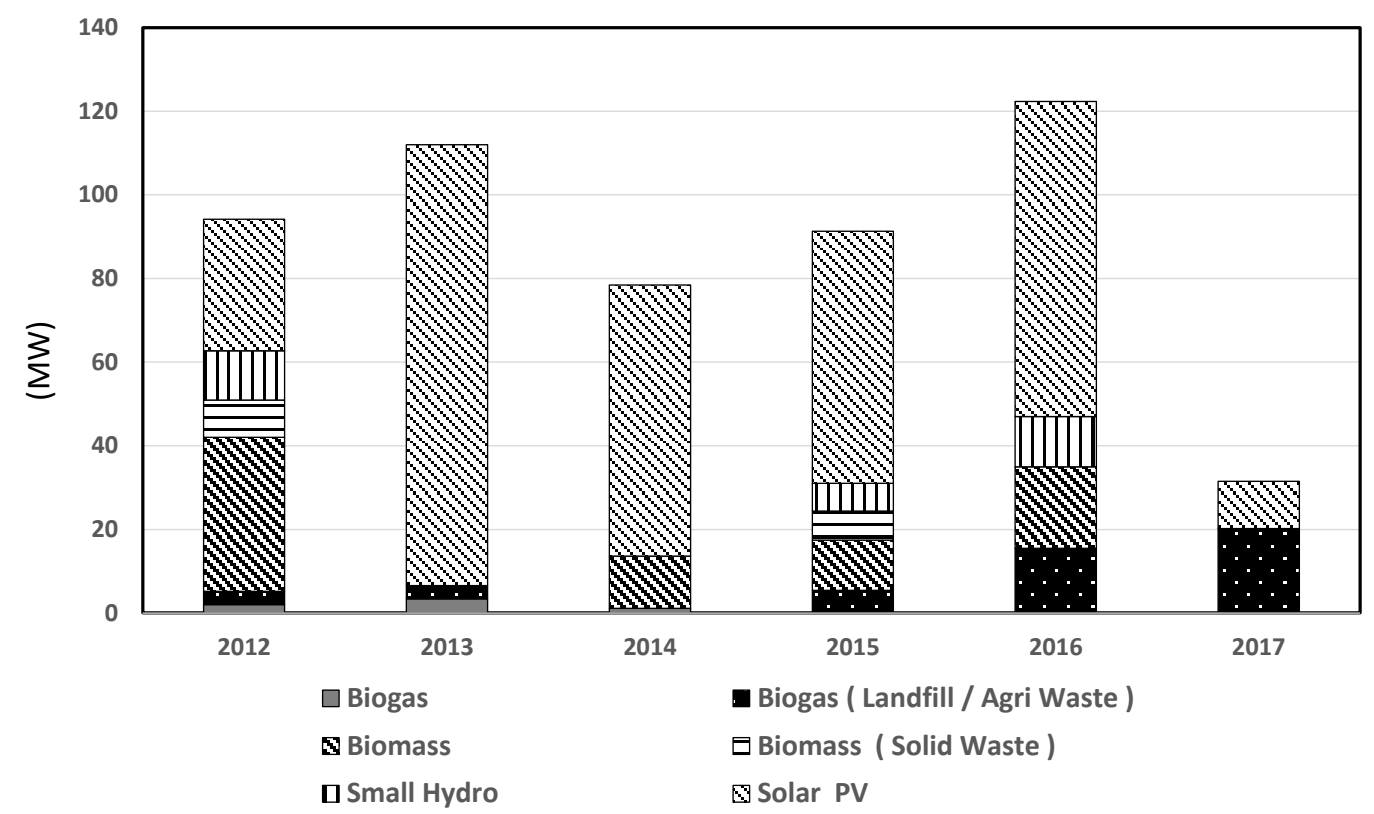

Figure 18. Installed Capacity (MW) of Commissioned RE Installations (FiT Program) [90].

Future research is required on rural public acceptance of RE technology to obtain overviews of rural residents' approval of this technology. Future studies on rural public perception include: the questionnaire should cover more aspects and scope in rural public acceptance study, such as "family socioeconomic background", "willingness to pay", "public concern about climate change" and "level of trust on RE", so that more detailed information regarding public attitudes toward RE can be obtained. The survey should be carried out on the entire rural area of Malaysia with different economic and geographic backgrounds since there are possibilities that different rural regions could give different attitudes and opinions regarding RE. In addition, a bigger sample or the inclusion of more interviewees might improve the quality of the data.

Author Contributions: M.A.M.S., N.M., A.J., S.M., A.B.A.R. and A.Z. designed and conducted the survey; M.A.M.S. analyzed the data; M.A.M.S, K.S. and N.M. wrote the paper. All of authors contributed to read and approved the final manuscript. All authors have read and agreed to the published version of the manuscript.

Funding: This work was supported by Universiti Kebangsaan Malaysia (grant number DIP-2018-038 and AP-2015-003). 
Acknowledgments: The authors would also like to thank all the residents of Kampung Tanjung Resang for their cooperation during the survey.

Conflicts of Interest: The authors declare no conflict of interest.

\section{References}

1. Malaysia Energy Commission. National Energy Balance 2014. 2016. Available online: http://meih.st.gov.my/ documents/10620/5bb0f85c-fc99-4743-a8a9-8ee0d65f1299 (accessed on 30 November 2019).

2. Ang, J.B. Economic development, pollutant emissions and energy consumption in Malaysia. J. Policy Model. 2008, 30, 271-278. [CrossRef]

3. Malaysia Energy Information Hub. Statistics. Available online: http://meih.st.gov.my/statistics (accessed on 3 December 2019).

4. Azlina, A.A. Energy consumption and economic development in Malaysia: A multivariate cointegration analysis. Procedia Soc. Behav. Sci. 2012, 65, 674-681. [CrossRef]

5. Mekhilef, S.; Barimani, M.; Safari, A.; Salam, Z. Malaysia's renewable energy policies and programs with green aspects. Renew. Sustain. Energy Rev. 2014, 40, 497-504. [CrossRef]

6. Bujang, A.S.; Bern, C.J.; Brumm, T.J. Summary of energy demand and renewable energy policies in Malaysia. Renew. Sustain. Energy Rev. 2016, 53, 1459-1467. [CrossRef]

7. Petinrin, J.O.; Shaaban, M. Renewable energy for continuous energy sustainability in Malaysia. Renew. Sustain. Energy Rev. 2015, 50, 967-981. [CrossRef]

8. Maggio, G.; Cacciola, G. When will oil, natural gas, and coal peak? Fuel 2012, 98, 111-123. [CrossRef]

9. Chua, S.C.; Oh, T.H. Review on Malaysia's national energy developments: Key policies, agencies, programmes and international involvements. Renew. Sustain. Energy Rev. 2010, 14, 2916-2925. [CrossRef]

10. Oh, T.H.; Pang, S.Y.; Chua, S.C. Energy policy and alternative energy in Malaysia: Issues and challenges for sustainable growth. Renew. Sustain. Energy Rev. 2010, 14, 1241-1252. [CrossRef]

11. Panwar, N.L.; Kaushik, S.C.; Kothari, S. Role of renewable energy sources in environmental protection: A review. Renew. Sustain. Energy Rev. 2011, 15, 1513-1524. [CrossRef]

12. Höök, M.; Tang, X. Depletion of fossil fuels and anthropogenic climate change-A review. Energy Policy 2013, 52, 797-809. [CrossRef]

13. Safaai, N.S.; Noor, Z.Z.; Hashim, H.; Ujang, Z.; Talib, J. Projection of $\mathrm{CO}_{2}$ emissions in Malaysia. Environ. Prog. Sustain. Energy 2011, 30, 658-665. [CrossRef]

14. Davis, S.J.; Caldeira, K.; Matthews, H.D. Future $\mathrm{CO}_{2}$ emissions and climate change from existing energy infrastructure. Science 2010, 329, 1330-1333. [CrossRef] [PubMed]

15. Shaffer, G.; Olsen, S.M.; Pedersen, J.O. Long-term ocean oxygen depletion in response to carbon dioxide emissions from fossil fuels. Nat. Geosci. 2009, 2, 105-109. [CrossRef]

16. CDIAC; UNFCCC; BP. Global and Malaysian Carbon Dioxide Emission. Available online: http://emissions2015. globalcarbonatlas.org/\# (accessed on 3 December 2019).

17. Moula, M.M.; Maula, J.; Hamdy, M.; Fang, T.; Jung, N.; Lahdelma, R. Researching social acceptability of renewable energy technologies in Finland. Int. J. Sustain. Built Environ. 2013, 2, 89-98. [CrossRef]

18. Mohamed, A.R.; Lee, K.T. Energy for sustainable development in Malaysia: Energy policy and alternative energy. Energy Policy 2006, 34, 2388-2397. [CrossRef]

19. Hashim, H.; Ho, W.S. Renewable energy policies and initiatives for a sustainable energy future in Malaysia. Renew. Sustain. Energy Rev. 2011, 15, 4780-4787. [CrossRef]

20. Ministry of Energy, Water and Communication (KeTTHA). National Renewable Energy Policy and Action Plan; Ministry of Energy, Water and Communication: Kuala Lumpur, Malaysia, 2016. Available online: http://www.seda.gov.my/ (accessed on 13 November 2019).

21. Oh, T.H.; Hasanuzzaman, M.; Selvaraj, J.; Teo, S.C.; Chua, S.C. Energy policy and alternative energy in Malaysia: Issues and challenges for sustainable growth-An update. Renew. Sustain. Energy Rev. 2017, 81, 3021-3031. [CrossRef]

22. Sustainable Energy Development Authority Malaysia (SEDA). Renewable Energy Installed Capacities. Available online: http://www.seda.gov.my/statistics-monitoring/re-installed-capacities/ (accessed on 13 November 2019).

23. Sustainable Energy Development Authority Malaysia (SEDA). Renewable Energy Generation. Available online: http://www.seda.gov.my/statistics-monitoring/re-generation/ (accessed on 13 November 2019). 
24. New Starts Times (NST). Construction of TNB's Large Scale Solar Project to Start Next Month. 2017. Available online: https://www.nst.com.my/business/2017/06/245654/construction-tnbs-large-scale-solar-project-startnext-month (accessed on 13 November 2019).

25. New Starts Times (NST). TNB's Mukim Tanjung 12 LSS Contributes 73.2 MW of RE to National Grid. 2018. Available online: https://www.nst.com.my/business/2018/12/437586/tnbs-mukim-tanjung-12-1ss-contributes732-mw-re-national-grid (accessed on 10 March 2020).

26. Marine Ecosystem Research Centre (EKOMAR). Available online: http://www.ukm.my/ekomar/about-us/ (accessed on 12 December 2019).

27. Amin, N.; Lung, C.W.; Sopian, K. A practical field study of various solar cells on their performance in Malaysia. Renew. Energy 2009, 34, 1939-1946. [CrossRef]

28. Chua, S.C.; Oh, T.H. Solar energy outlook in Malaysia. Renew. Sustain. Energy Rev. 2012, 16, 564-574. [CrossRef]

29. Mekhilef, S.; Safari, A.; Mustaffa, W.E.; Saidur, R.; Omar, R.; Younis, M.A. Solar energy in Malaysia: Current state and prospects. Renew. Sustain. Energy Rev. 2012, 16, 386-396. [CrossRef]

30. Ahmad, S.; Ab Kadir, M.Z.; Shafie, S. Current perspective of the renewable energy development in Malaysia. Renew. Sustain. Energy Rev. 2011, 15, 897-904. [CrossRef]

31. Haris, A.H. MBIPV Project: Catalyzing local PV Market. Finance and Investment Forum on PV Technology. 2008. Available online: http://www.mbipv.net.my/dload/fif-hh.pdf (accessed on 5 December 2019).

32. Masseran, N.; Razali, A.M.; Ibrahim, K. An analysis of wind power density derived from several wind speed density functions: The regional assessment on wind power in Malaysia. Renew. Sustain. Energy Rev. 2012, 16, 6476-6487. [CrossRef]

33. Masseran, N.; Razali, A.M.; Ibrahim, K.; Zin, W.W.; Zaharim, A. On spatial analysis of wind energy potential in Malaysia. WSEAS Trans. Math. 2012, 11, 467-477.

34. Sopian, K.; Othman, M.H.; Wirsat, A. The wind energy potential of Malaysia. Renew. Energy 1995, 6, $1005-1016$. [CrossRef]

35. Borhanazad, H.; Mekhilef, S.; Saidur, R.; Boroumandjazi, G. Potential application of renewable energy for rural electrification in Malaysia. Renew. Energy 2013, 59, 210-219. [CrossRef]

36. Del Río, P.; Burguillo, M. Assessing the impact of renewable energy deployment on local sustainability: Towards a theoretical framework. Renew. Sustain. Energy Rev. 2008, 12, 1325-1344. [CrossRef]

37. Del Rio, P.; Burguillo, M. An empirical analysis of the impact of renewable energy deployment on local sustainability. Renew. Sustain. Energy Rev. 2009, 13, 1314-1325. [CrossRef]

38. Walker, G. Renewable energy and the public. Land Use Policy 1995, 12, 49-59. [CrossRef]

39. Wüstenhagen, R.; Wolsink, M.; Bürer, M.J. Social acceptance of renewable energy innovation: An introduction to the concept. Energy Policy 2007, 35, 2683-2691. [CrossRef]

40. Sütterlin, B.; Siegrist, M. Public acceptance of renewable energy technologies from an abstract versus concrete perspective and the positive imagery of solar power. Energy Policy 2017, 106, 356-366. [CrossRef]

41. Aklin, M.; Cheng, C.Y.; Urpelainen, J. Social acceptance of new energy technology in developing countries: A framing experiment in rural India. Energy Policy 2018, 113, 466-477. [CrossRef]

42. Devine-Wright, P. Reconsidering public attitudes and public acceptance of renewable energy technologies: A critical review. In Beyond Nimbyism: A Multidisciplinary Investigation of Public Engagement with Renewable Energy Technologies; Manchester, UK, 2007; Available online: http://geography.exeter.ac.uk/beyond_nimbyism/ deliverables/bn_wp1_4.pdf (accessed on 13 November 2019).

43. Devine-Wright, P. Place attachment and public acceptance of renewable energy: A tidal energy case study. J. Environ. Psychol. 2011, 31, 336-343. [CrossRef]

44. Tanujaya, R.R.; Lee, C.Y.; Woo, J.; Huh, S.Y.; Lee, M.K. Quantifying public preferences for community-based renewable energy projects in South Korea. Energies 2020, 13, 2384. [CrossRef]

45. Wolsink, M. Undesired reinforcement of harmful 'self-evident truths' concerning the implementation of wind power. Energy Policy 2012, 48, 83-87. [CrossRef]

46. Seidl, R.; Von Wirth, T.; Krütli, P. Social acceptance of distributed energy systems in Swiss, German, and Austrian energy transitions. Energy Res. Soc. Sci. 2019, 54, 117-128. [CrossRef]

47. Zoellner, J.; Schweizer-Ries, P.; Wemheuer, C. Public acceptance of renewable energies: Results from case studies in Germany. Energy Policy 2008, 36, 4136-4141. [CrossRef] 
48. Jobert, A.; Laborgne, P.; Mimler, S. Local acceptance of wind energy: Factors of success identified in French and German case studies. Energy Policy 2007, 35, 2751-2760. [CrossRef]

49. Soland, M.; Steimer, N.; Walter, G. Local acceptance of existing biogas plants in Switzerland. Energy Policy 2013, 61, 802-810. [CrossRef]

50. Kortsch, T.; Hildebrand, J.; Schweizer-Ries, P. Acceptance of biomass plants-Results of a longitudinal study in the bioenergy-region Altmark. Renew. Energy 2015, 83, 690-697. [CrossRef]

51. Schumacher, K.; Schultmann, F. Local acceptance of biogas plants: A comparative study in the Trinational Upper Rhine Region. Waste Biomass Valorization 2017, 8, 2393-2412. [CrossRef]

52. Scherhaufer, P.; Höltinger, S.; Salak, B.; Schauppenlehner, T.; Schmidt, J. A participatory integrated assessment of the social acceptance of wind energy. Energy Res. Soc. Sci. 2018, 45, 164-172. [CrossRef]

53. Liu, W.; Wang, C.; Mol, A.P. Rural public acceptance of renewable energy deployment: The case of Shandong in China. Appl. Energy 2013, 102, 1187-1196. [CrossRef]

54. Hanley, N.; Nevin, C. Appraising renewable energy developments in remote communities: The case of the North Assynt Estate, Scotland. Energy Policy 1999, 27, 527-547. [CrossRef]

55. Borchers, A.M.; Duke, J.M.; Parsons, G.R. Does willingness to pay for green energy differ by source? Energy Policy 2007, 35, 3327-3334. [CrossRef]

56. Hosseini, A.; Zolfagharzadeh, M.M.; Asghar Sadabadi, A.; Aslani, A.; Jafari, H. Social acceptance of renewable energy in developing countries: Challenges and opportunities. Distrib. Gener. Altern. Energy J. 2018, 33, 31-48. [CrossRef]

57. Lim, X.L.; Lam, W.H. Public acceptance of marine renewable energy in Malaysia. Energy Policy 2014, 65, 16-26. [CrossRef]

58. Kardooni, R.; Yusoff, S.B.; Karim, F.B. Renewable energy technology acceptance in Peninsular Malaysia. Energy Policy 2016, 88, 1-10. [CrossRef]

59. Kardooni, R.; Yusoff, S.B.; Kari, F.B.; Moeenizadeh, L. Public opinion on renewable energy technologies and climate change in peninsular Malaysia. Renew. Energy 2018, 116, 659-668. [CrossRef]

60. Fadaeenejad, M.; Radzi, M.A.; AbKadir, M.Z.; Hizam, H. Assessment of hybrid renewable power sources for rural electrification in Malaysia. Renew. Sustain. Energy Rev. 2014, 30, 299-305. [CrossRef]

61. Halili, S.H.; Sulaiman, H. Factors influencing the rural students' acceptance of using ICT for educational purposes. Kasetsart J. Soc. Sci. 2018. [CrossRef]

62. Google 2019. Available online: https://maps.googleapis.com/maps/api/staticmap?center=2.58,103.806\&zoom= $13 \&$ size $=640 \times 640 \&$ scale=2\&maptype=terrain\&language $=$ en-EN\&key=xxx (accessed on 15 December 2019).

63. Babakus, E.; Mangold, W.G. Adapting the SERVQUAL scale to hospital services: An empirical investigation. Health Serv. Res. 1992, 26, 767-786. [PubMed]

64. Cortese, A.D. The critical role of higher education in creating a sustainable future. Plan. High. Educ. 2003, 31, $15-22$.

65. Stephens, J.C.; Hernandez, M.E.; Román, M.; Graham, A.C.; Scholz, R.W. Higher education as a change agent for sustainability in different cultures and contexts. Int. J. Sustain. High. Educ. 2008, 9, 317-338. [CrossRef]

66. Department of Statistics Malaysia (DOSM). Press Release Report of Household Income and Basic Amenities Survey 2014. 2015. Available online: https://www.dosm.gov.my/v1/index.php?r=column/pdfPrev\&id= aHhtTHVWNVYzTFBua2dSU1BRL1Rjdz09 (accessed on 30 December 2019).

67. Weigt, H. Germany's wind energy: The potential for fossil capacity replacement and cost saving. Appl. Energy 2009, 86, 1857-1863. [CrossRef]

68. Eltham, D.C.; Harrisonm, G.P.; Allen, S.J. Change in public attitudes towards a Cornish wind farm: Implications for planning. Energy Policy 2008, 36, 23-33. [CrossRef]

69. Frantál, B.; Kunc, J. Wind turbines in tourism landscapes: Czech experience. Ann. Tour. Res. 2011, 38, 499-519. [CrossRef]

70. Frantál, B.; Urbánková, R. Energy tourism: An emerging field of study. Curr. Issues Tour. 2017, 20, 1395-1412. [CrossRef]

71. de Sousa, A.J.; Kastenholz, E. Wind farms and the rural tourism experience-problem or possible productive integration? The views of visitors and residents of a Portuguese village. J. Sustain. Tour. 2015, 23, 1236-1256. [CrossRef]

72. Beer, M.; Rybár, R.; Ka'avský, M. Renewable energy sources as an attractive element of industrial tourism. Curr. Issues Tour. 2018, 21, 2139-2151. [CrossRef] 
73. Molnarova, K.; Sklenicka, P.; Stiborek, J.; Svobodova, K.; Salek, M.; Brabec, E. Visual preferences for wind turbines: Location, numbers and respondent characteristics. Appl. Energy 2012, 92, 269-278. [CrossRef]

74. Strazzera, E.; Mura, M.; Contu, D. Combining choice experiments with psychometric scales to assess the social acceptability of wind energy projects: A latent class approach. Energy Policy 2012, 48, 334-347. [CrossRef]

75. Broekel, T.; Alfken, C. Gone with the wind? The impact of wind turbines on tourism demand. Energy Policy 2015, 86, 506-519. [CrossRef]

76. Teisl, M.F.; Noblet, C.L.; Corey, R.R.; Giudice, N.A. Seeing clearly in a virtual reality: Tourist reactions to an offshore wind project. Energy Policy 2018, 122, 601-611. [CrossRef]

77. Michalena, E.; Hills, J.; Amat, J.P. Developing sustainable tourism, using a multicriteria analysis on renewable energy in Mediterranean Islands. Energy Sustain. Dev. 2009, 13, 129-136. [CrossRef]

78. Michalena, E.; Tripanagnostopoulos, Y. Contribution of the solar energy in the sustainable tourism development of the Mediterranean islands. Renew. Energy 2010, 35, 667-673. [CrossRef]

79. Brau, R. Demand-driven sustainable tourism? A choice modelling analysis. Tour. Econ. 2008, 14, $691-708$. [CrossRef]

80. Sadat, M.M.; Chang, L.H. The impact of environmental quality of revisiting intention. J. Qual. Assur. Hosp. Tour. 2016, 17, 209-223. [CrossRef]

81. Zakhidov, R.A. Central Asian countries energy system and role of renewable energy sources. Appl. Sol. Energy 2008, 44, 218-223. [CrossRef]

82. Chong, H.Y.; Lam, W.H. Ocean renewable energy in Malaysia: The potential of the Straits of Malacca. Renew. Sustain. Energy Rev. 2013, 23, 169-178. [CrossRef]

83. Omer, A.M. Energy, environment and sustainable development. Renew. Sustain. Energy Rev. 2008, 12, $2265-2300$. [CrossRef]

84. Chen, W.N. Renewable Energy Status in Malaysia. SEDA. 2012. Available online: http://www.mida.gov.my/ env3/uploads/events/Sabah04122012/SEDA.pdf (accessed on 30 December 2019).

85. Malek, B.A. Renewable energy development in Malaysia. In Proceedings of the APEC Expert Group on New and Renewable Energy Technologies (EGNRET) 34th Meeting, Kuala Lumpur, Malaysia, 26-28 April 2010.

86. Kandpal, T.C.; Broman, L. Renewable energy education: A global status review. Renew. Sustain. Energy Rev. 2014, 34, 300-324. [CrossRef]

87. Acikgoz, C. Renewable energy education in Turkey. Renew. Energy 2011, 36, 608-611. [CrossRef]

88. Jennings, P. New directions in renewable energy education. Renew. Energy 2009, 34, 435-439. [CrossRef]

89. Jennings, P.; Lund, C. Renewable energy education for sustainable development. Renew. Energy 2001, 22, 113-118. [CrossRef]

90. Sustainable Energy Development Authority Malaysia (SEDA). Installed Capacity (MW) of Commissioned RE Installations (FiT Program). Available online: http://www.seda.gov.my/feed-in-tarif-fit/renewable-resources/ (accessed on 5 January 2020).

(C) 2020 by the authors. Licensee MDPI, Basel, Switzerland. This article is an open access article distributed under the terms and conditions of the Creative Commons Attribution (CC BY) license (http://creativecommons.org/licenses/by/4.0/). 